\title{
Peculiar calcite speleothems filling fissures in calcareous sandstones and their palaeohydrological and palaeoclimatic significance: an example from the Polish Carpathians
}

\author{
Michał GRADZIŃSKI, Marek DULIŃSKI, Helena HERCMAN, \\ Andrzej GÓRNY and Stanisław PRZYBYSZOWSKI
}

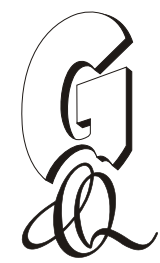

\begin{abstract}
Gradziński M., Duliński M., Hercman H., Górny A. and Przybyszowski S. (2012) - Peculiar calcite speleothems filling fissures in calcareous sandstones and their palaeohydrological and palaeoclimatic significance: an example from the Polish Carpathians. Geol. Quart., 56 (4): 711-732, doi: 10.7306/gq.1051

Peculiar calcite speleothems developed in fissures in the Cergowa Sandstones were found in the Klęczany Quarry (Polish Western Carpathians). They represent flowstone and stalactites, rafts and various sparry crusts. Such speleothems, especially phreatic ones, are uncommon in the Outer Carpathians that are composed mainly of siliciclastic rocks of flysch type, with only limited calcium carbonate content. The speleothems analysed grew in vadose and phreatic conditions as well as at the air-water interface. Phreatic speleothems and thin rafts comprise calcite crystals of eccentric morphology. Based on their stable isotope composition the majority of the speleothems form two clusters. The first is characterized by $\delta^{18} \mathrm{O}$ values between -9.8 and $-8.5 \%$ and of $\delta^{13} \mathrm{C}$ values between -5.7 and $-0.6 \%$ whereas the second cluster of samples yields $\delta^{18} \mathrm{O}$ values between -9.4 and $-7.3 \%$ and $\delta^{13} \mathrm{C}$ values from -11.5 to $-9.7 \%$. Speleothems grew between $230_{-13}^{+14} \mathrm{ka}$ and Holocene time. Phreatic speleothems, including massive rafts, precipitated from ascending water of deep circulation whereas vadose and water table speleothems crystallized from local infiltration water charged with soil $\mathrm{CO}_{2}$. Mixing of both waters in the shallow phreatic zone is plausible.

Michat Gradziński, Institute of Geological Sciences, Jagiellonian University, Oleandry 2a, 30-063 Kraków, Poland, e-mail: michal.gradzinski@uj.edu.pl; Marek Duliński. Faculty of Physics and Applied Computer Science, AGH University of Science and Technology, Mickiewicza 30, 30-059 Kraków, Poland, e-mail: marek.dulinski@ fis.agh.edu.pl; Helena Hercman, Institute of Geological Sciences, Polish Academy of Sciences, Twarda 51/55, 00-818 Warszawa, Poland, e-mail: hhercman@twarda.pan.pl; Andrzej Górny, Geological Museum, Faculty of Geology, Geophysics and Environment Protection, AGH University of Science and Technology, Mickiewicza 30 30-059 Kraków, Poland, e-mail: a.gorn@op.pl; Stanistaw Przybyszowski, Klęczany Stone Resources Company Ltd, 33-394 Klęczany 176 Poland, present address: Wasza Agencja Turystyczna SZKOLTUR, Mariusz Borkowski, 11 Listopada 25; 33-340, Stary Sacz, Poland, e-mail: atwns@interia.pl (received: May 2, 2012; accepted: July 13, 2012; first published online: October 22, 2012).
\end{abstract}

Key words: Flysch Carpathians, Pleistocene, Holocene, speleothems, stable isotopes, ascending water.

\section{INTRODUCTION}

Various subsurface cavities, either of karst or gravitational origin, that formed in carbonate rocks, are filled with secondary carbonates. They display a wide spectrum of morphological forms from common such as dripstones or flowstones to more unusual forms such as, for instance, helictites (Hill and Forti, 1997). They are collectively named speleothems. Those originating in a vadose zone, that is over the water table, are fed by seepage water. There also other speleothems exist the growth of which takes place in phreatic conditions or is strictly limited to the water table. Calcite spar is a typical phreatic speleothem growing below the water table. It consists of relatively large calcite crystals lining walls of subsurface cavities. Calcite rafts, lilypads, and shelfstones - called also ledges - represent speleothems growing at, or just beneath the water table (Jones, 1989; Hill and Forti, 1997; Taylor and Chafetz, 2004). Similar forms are also known from springs, mainly those issuing mineral waters (Folk et al., 1985; Chafetz et al., 1991; Chafetz and Lawrence, 1994; Guo and Riding, 1998; Renaut et al., 1999; Fouke et al., 2000) as well as from some tropical streams (Taylor et al., 2004). Rafts filling fissures have also been recognized within a travertine mound (Kostecka, 1992).

Caves or fissures hosted by sandstones usually lack carbonate speleothems. If speleothems occur within sandstone caves, they are mostly limited to thin flowstones covering cave walls, and to small stalactites (Urban et al., 2007a, b; Bruthans et al., 2012). Phreatic and water table speleothems hardly ever occur within sandstones. Drusy calcites described by Kostecka and 
Węcławik (1987), Kostecka (1993) and Duliński et al. (1995) may serve as an example. However, they originated in unique conditions. They were formed within fractures acting as discharge passages for highly gasified mineral waters.

The unusual speleothems described here were found during exploitation of calcareous sandstones in the Klęczany Quarry (Beskid Wyspowy Mts., Polish Carpathians). They represent flowstones and stalactites, rafts and calcite spar. Some of them are composed of bizarre types of calcite crystals. To the best of the authors' knowledge, analogous speleothems have not so far been described from cavities within sandstone rocks. The main aim of the paper is: (1) to analyse their structures, age and stable isotope composition, (2) to explain their formation, and (3) to unravel factors controlling their growth.

\section{GEOLOGICAL SETTING}

The Polish segment of the Outer Carpathians comprises several northwards thrusted nappes. The nappes are underlain by Miocene deposits of the Carpathian Foredeep which in turn overlie the Mesozoic rocks of North European Platform (Oszczypko, 2008). The Outer Carpathian nappes are composed of various Upper Jurassic to Lower Miocene rocks. They are comprise predominantly siliciclastics, mainly of flysch type. The flysch type rocks comprise interbedded successions of sandstone-dominated and relatively fine-grained units. Rocks containing carbonates - calcareous sandstones and marlstones - occur subordinately while pure carbonates are exceptional (Leszczyński and Malik, 1996). However, some marls contain up to $56 \%$ of $\mathrm{CaCO}_{3}$ (Leszczyński and Malata, 2002).

The Klęczany Quarry is located in the area of the Klecczany-Limanowa Tectonic Window where folded rocks of the Fore-Magura Group crop out from beneath the Magura Nappe (Fig. 1; Cieszkowski, 1992; Cieszkowski and Ślączka, 2001). The rocks in the quarry represent mainly medium to thick-bedded Cergowa Sandstones, which are up to $500 \mathrm{~m}$ thick (Kowal, 2009). They are of Oligocene age. The beds of Cergowa Sandstones beds dip north-eastwards at an angle of $10-20^{\circ}$. Some packages within the Cergowa Sandstones are composed of amalgamated calcareous sandstone beds, of thickness exceeding a few metres whereas others are dominated by thin-bedded mudstones interbedded with fine-grained calcareous sandstones. The former are interpreted as submarine channel facies and the latter as levee and interchannel facies (Stadnik, 2009). The Cergowa Sandstones are composed of quartz, micas, carbonate grains and mudstone lithoclasts. Feldspar and glauconite grains occur subordinately (Cieszkowski, 1992; Kowal, 2009). The sandstones are cemented by calcite. The mean carbonate content in the Cergowa Sandstones is 24.9 wt.\%, whereas its maximum content reaches 35.6 wt.\% (Florek, 2009), which was confirmed by exploratory calcimetric analyses. Two dark mudstone beds occur within the upper part of the section exposed in the quarry. They are laminated and lack substantial amounts of carbonates (Kowal, 2009).

Speleothems were recognized in the autumn of 2004 in the eastern part of the quarry on exploitation level 1, located at an altitude of around $390 \mathrm{~m}$ (Fig. 2). Speleothems filled fracture and breccia type porosity in one massive calcareous sandstone bed. They were identified along a distance of approximately $120 \mathrm{~m}$.

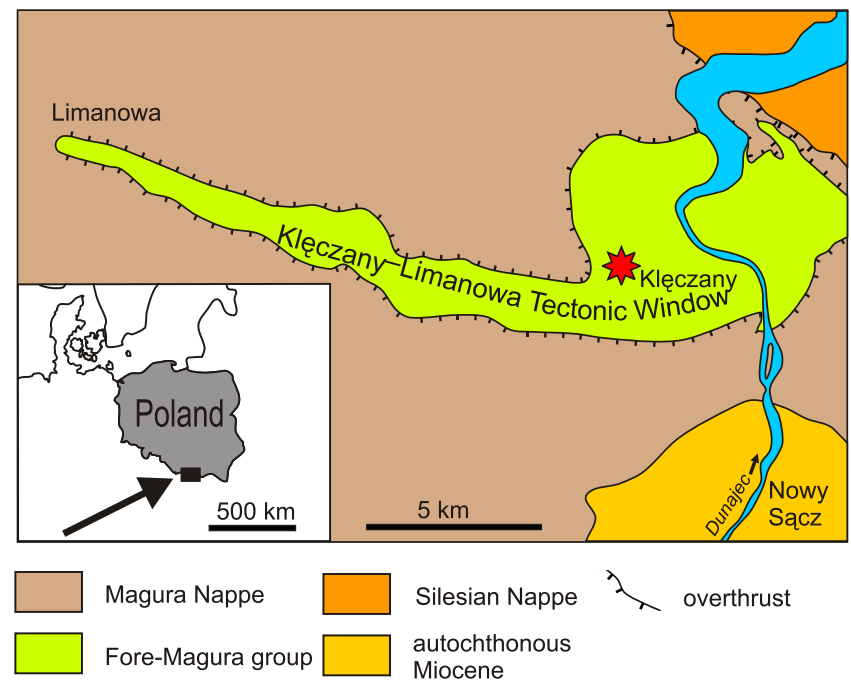

Fig. 1. Location of the Klęczany Quarry (asterisk), geology after Cieszkowski (1992)

The calcareous sandstone bed hosting speleothems was cut by fractures, probably faults with a small throw. The strike of fractures was approximately $25-205^{\circ}$ and their dip was vertical or subvertical which was westwards oriented. The fractures formed three zones within which calcareous sandstones were disintegrated into blocks from a few centimetres to $>1.8 \mathrm{~m}$ across. Some of the blocks were rotated, constituting megabreccia. The cavities between individual blocks are partly filled with speleothems, and part remain as open spaces.

The lithological variation of rocks in the Outer Carpathians determines the hydrogeological characteristics of this region. Generally, sandstone-dominated units act as water-bearing levels whereas fine-grained series are less permeable (Chowaniec, 2009). However, due to generally low matrix porosity of flysch sandstones, the fractured zones are particularly permeable (Oszczypko et al., 1981). Exploratory analyses show that the interconnected porosity of the Cergowa Sandstones is $1.9 \%$ (S. Borczak, 2012, personal information). The position of the water table had been checked before exploitation in the quarry started. In a borehole located around $100 \mathrm{~m}$ north-westward from the speleothems, it was determined at an attitude of $418 \mathrm{~m}$ :

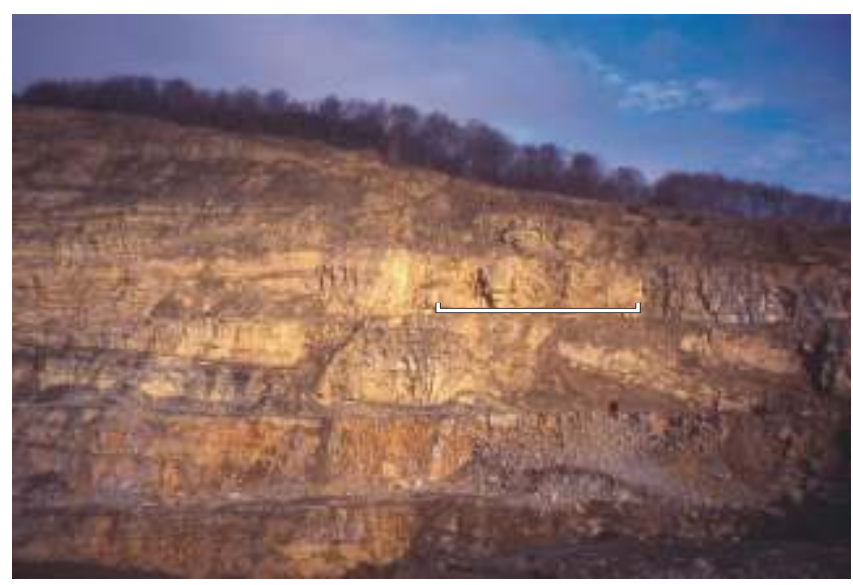

Fig. 2. General view of the Klęczany Quarry: zone of speleothem occurrence is indicated (photo taken in 2004) 
that is, approximately $25 \mathrm{~m}$ higher than the speleothems. Considering the direction and angle of the slope this suggests that the speleothems occur roughly near the former water table.

\section{MATERIALS AND METHODS}

Calcite-fill fissures were found during the quarrying of calcareous sandstones. Loose specimens were collected and delivered to the Geological Museum of the Faculty of Geology, Geophysics and Environment Protection, AGH University of Science and Technology (Kraków). Thus, the orientation of specimens and their detailed location are not known. The field situation could be studied during one trip when calcite-filled fissures had been almost completely quarried away. During this trip the sampling was nearly impossible mainly for the sake of safety. Nonetheless, some oriented samples were taken. Internal structures of the speleothems were studied using a petrographic microscope and by SEM. Two SEM microscopes were used: a JEOL 5410, coupled with a microprobe (EDS) Voyager 3100 (Noran product) and a Hitachi S-4700 coupled with a microprobe Vantage (Noran product).

Samples containing 2-10 g of clean, compact calcite with no visible traces of detrital admixtures were selected for U-Th dating which was performed at the Uranium-Series Laboratory at the Institute of Geological Sciences, Polish Academy of Sciences. The standard chemical procedure for uranium and thorium separation from carbonate samples was used (Ivanovich and Harmon, 1992). $\mathrm{A}^{228} \mathrm{Th}^{-232} \mathrm{U}$ mixture (UDP10030 tracer solution by Isotrac, AEA Technology) was used as an efficiency tracer of the chemical procedure. $U$ and Th were separated by ion exchange using DOWEX $1 \times 8$ resin. After final purification, $\mathrm{U}$ and $\mathrm{Th}$ were electro-deposited on steel disks. Energy spectra of alpha particles were collected using an DUO-ANSAMBLE spectrometer made by EG\&G ORTEC. Spectral analyses and age calculations were made using "URANOTHOR 2.6" software, which is standard software developed in the Uranium-Series Laboratory in Warsaw (Gorka and Hercman, 2002). Each spectrum was corrected for background and delay time between chemical separation and measurement. The uranium content in all samples was high enough for precise measurement $(0.143-0.67 \mathrm{ppm})$.

Measurements of carbon and oxygen isotope composition were performed on gaseous carbon dioxide evolved in the reaction of carbonates with $100 \%$ orthophosphoric acid at $25^{\circ} \mathrm{C}$. Analyses were made using a Finnigan Delta $S$ mass spectrometer at the Mass Spectrometry Laboratory, Faculty of Physics and Applied Computer Science, AGH University of Science and Technology, Kraków.

Geochemical analyses were carried out in ACMELabs (Vancouver, Canada). ICP-emission spectrometry for major oxides was used, whereas other elements are determined by ICP Mass Spectrometry; total carbon and sulphur were analysed by Leco.

\section{RESULTS AND INTERPRETATION}

\section{PETROGRAPHY}

Three main types of speleothem were recognized in the Klęczany Quarry: (1) vadose speleothems, (2) rafts, and (3) phreatic crusts. Calcite is the only autochthonous mineral phase composing the speleothems, which was demonstrated by X-ray diffractometry and infrared absorption spectroscopy.

\section{FLOWSTONES AND STALACTITES}

Vadose speleothems are represented by flowstones and stalactites. They have a perfectly smooth, shiny surface which is yellowish-gray in colour. Flowstones developed on overhangs form small vertical ribs which continue down and transit into small stalactites up to $1 \mathrm{~cm}$ across and up to $6 \mathrm{~cm}$ long (Fig. 3A). Flowstone thickness ranges from a few millimetres up to $5 \mathrm{~cm}$ (Fig. 3B, C).

Both flowstones and stalactites display layering visible with the naked eye. Brownish layers interfinger with lighter and more translucent ones. The thickness of the former exceeds $2 \mathrm{~cm}$, whereas the thickness of the latter varies from 0.02 to $0.3 \mathrm{~mm}$. The boundaries between laminae are sharp.

The vadose speleothems are composed predominantly of elongated, columnar crystals, more than $10 \mu \mathrm{m}$ across (see Kendall and Broughton, 1978). Their length exceeds $2 \mathrm{~mm}$ whereas their maximum width is almost $1 \mathrm{~mm}$. Generally, the crystals widen upwards, that is out of the nucleation surface. The crystals are densely packed. Empty spaces between them occur only in the subsurface part of a speleothem, that is just beneath the growing faces of the crystals. Most of the crystals display flat termination, which is visible both in thin section and under SEM (Fig. 3D). Flat terminations are triangular in shape. Small holes, some of them also triangular in cross-section, are present in some of them (Fig. 3E).

Some of the speleothems are composed of a single layer of crystals, the thickness of which equals the length of crystals. In this case only one nucleation surface occurs; it is located on the calcareous sandstone/speleothem boundary. In other speleothems a few additional nucleation surfaces exist (Fig. 3F). Such nucleation surfaces are the result of accumulation of detrital impurities forming distinct bands. The dimensions and optic orientation of columnar crystals change with distance away from nucleation surfaces (Fig. 3G). As the width of crystals increases, their optic orientation becomes more uniform. The amount of crystals clearly decreases away from nucleation surfaces. Thus, they display competitive growth (sensu González et al., 1992) or an impingement crystallization pattern (sensu Dickson, 1993).

Some laminae, dark brown in plane polarized light, occur within the speleothems, which is a typical feature of vadose flowstones. Most of these are horizontal with some irregularities near boundaries of adjacent crystals. Only a few of them display serrated patterns (Fig. $3 \mathrm{H}$ ). 

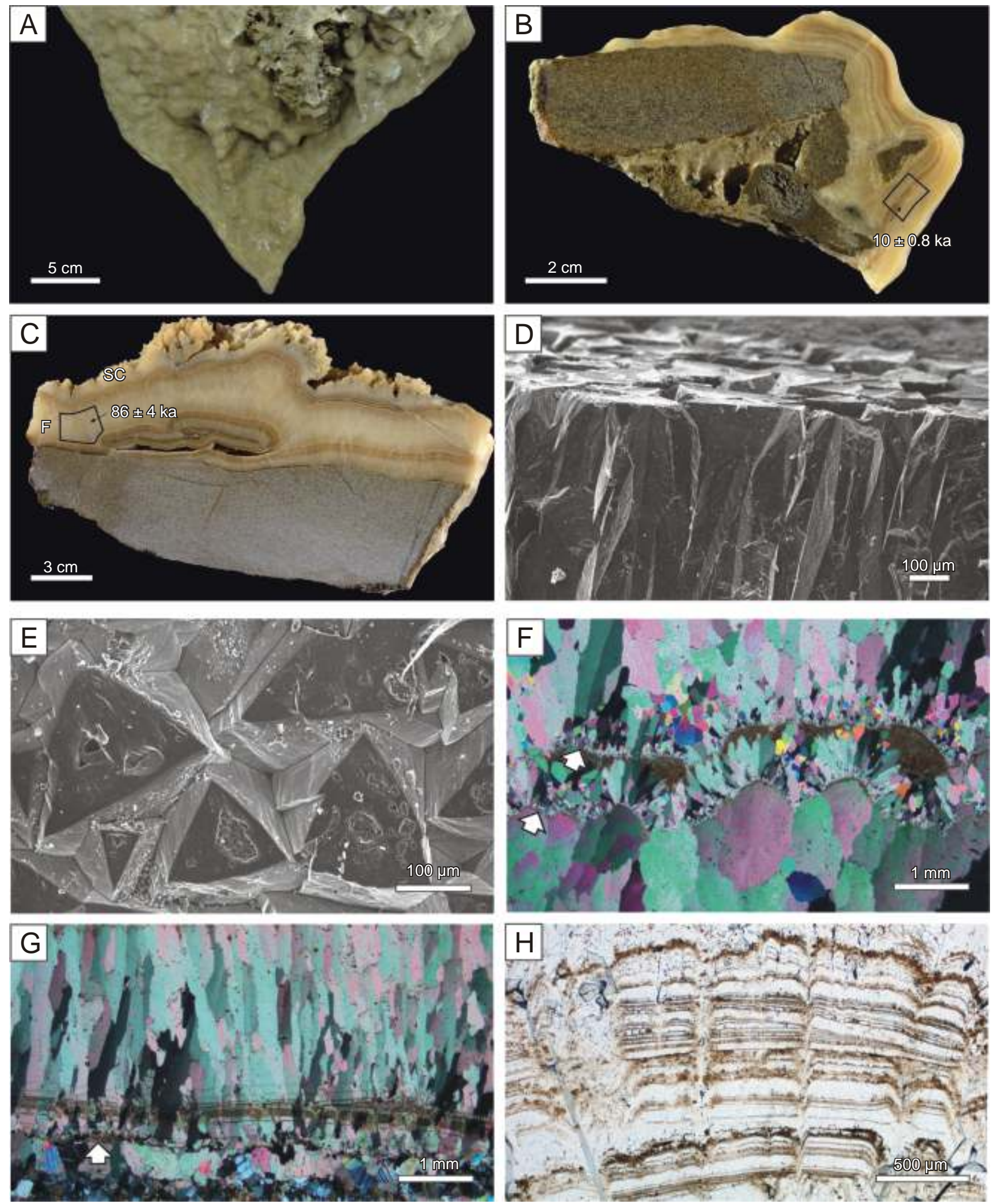

Fig. 3. Vadose speleothems

$\mathbf{A}$ - flowstone and small stalactite; $\mathbf{B}$ - laminated flowstone, cross-section; $\mathbf{C}$ - laminated flowstone (F) covered with sparry crusts (SC), dating result is indicated, cross-section; D - broken section and surface of flowstone, note columnar calcite crystals with flat terminations (SEM image); E - flowstone surface view from the top, note small holes in some crystals (SEM image); $\mathbf{F}$ - three layers of crystals composing flowstone, two nucleation surfaces are visible (arrows), transmitted light (crossed polars); $\mathbf{G}$ - single layer of columnar crystals, note their increasing width and more uniform optic orientation towards the top, nucleation surface is arrowed, transmitted light (crossed polars); $\mathbf{H}$ - lamination within columnar crystals, laminae mark former position of crystal terminations, transmitted light; position of dated samples and their ages are shown in B and C 
The morphology of vadose speleothems, that is of flowstones and stalactites, shows that they were fed by seepage water. Their most characteristic feature is extremely smooth, even lustrous surfaces, the origin of which can be explained in two different ways. Kendall and Broughton (1978) suggested that the thin film of parent water resulted in the smooth surface of the growing speleothems. This idea was extended to calcite crystals present outside of speleothems also (Binkley et al., 1980; Kostecka, 1993; Gradziński et al., 1997; Turgeon and Lundberg, 2001). Conversely, Frisia et al. (2000) explained the flat faces of crystals located at the tips of active stalagmites by invoking a spiral growth mechanism. In the case studied, however, the former cause seems to be more probable. This is suggested by the occurrence of such surfaces exclusively in speleothems of vadose morphology, that is in flowstones and stalactites. The clear boundary between smooth flowstones deposited over, and calcite spar formed beneath, a water table is clearly visible in some specimens (Fig. 4).

The presence of holes located in the central part of some flat crystal faces also supports the above view (Fig. 3E). The holes most probably were formed when a crystal reached the parent water-air boundary and its central part started to suffer from water deficiency. This caused more efficient growth of the pe-

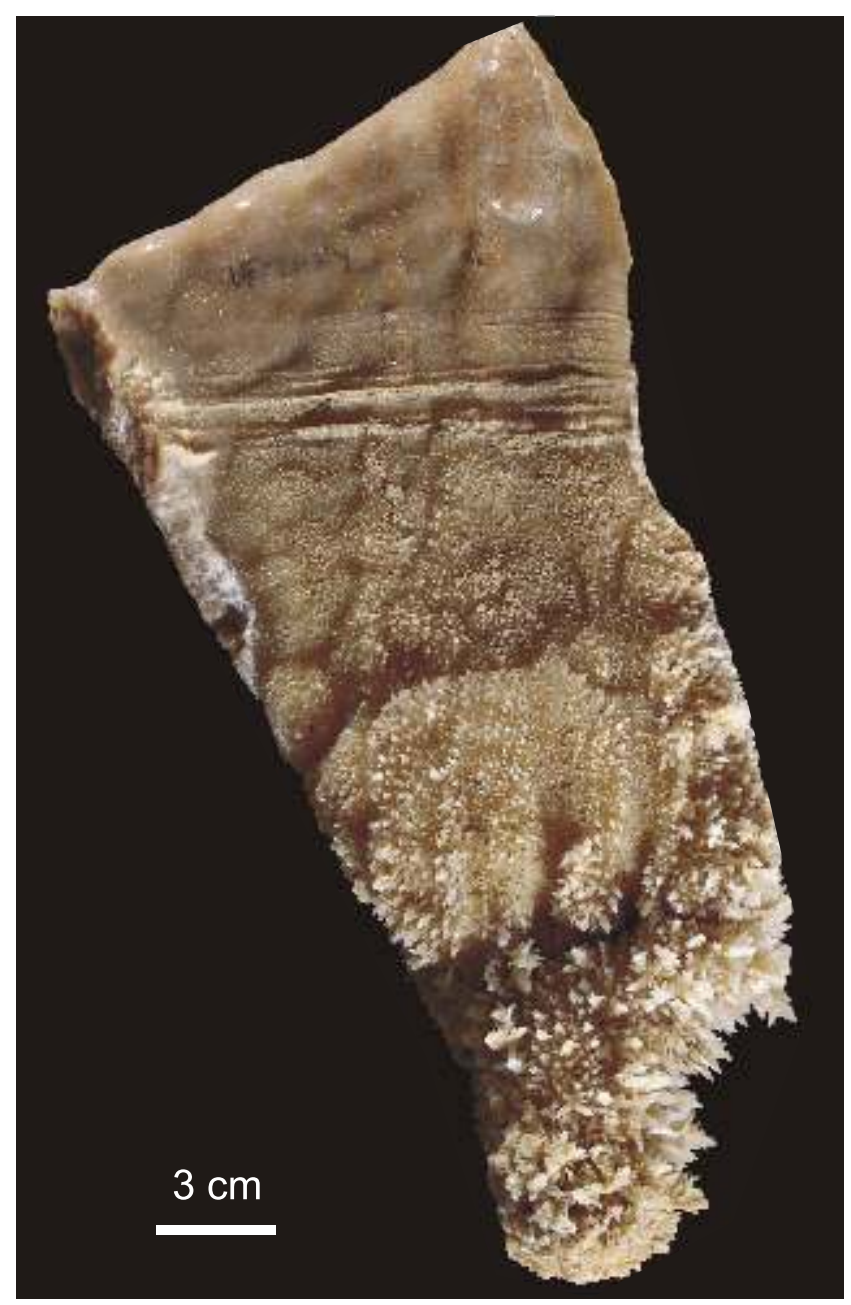

Fig. 4. Flowstone covering a sandstone block passing down to a sparry crust, subtle changes in position of water table are visible due to a series of well-developed shelfstones riphery of the crystal, which led to creation of a hole in its central part. Hence, this suggests the presence of extremely thin film of parent water. A similar mechanism was described by Wells (1971, fig. 53) in relation to hopper-type crystals formed in cave pools that reached the air-water interface.

THIN RAFTS

Thin rafts constitute plate-like tablets composed of various calcite crystals. They are found as loose, single objects littering the fissure floors. They are partly broken; however, the primary edges are still preserved in some cases (Fig. 5A, B). Their colour is milky white; some larger crystals are semitranslucent. They are a few centimetres in lateral extent whereas their thickness ranges from less than a millimetre to almost $3 \mathrm{~mm}$; however, in the latter case the raft is not a robust tablet but has a serrated appearance. The rafts are considerably thicker than most of those described so far from caves and hot springs. The thickness of cave rafts usually do not exceed $1 \mathrm{~mm}$ (Hill and Forti, 1997, p. 88), and commonly they are considerably thinner. For example, the average thickness of rafts from Gorman Cave (Texas) was $30 \mu \mathrm{m}$ whereas their maximum thickness reached $130 \mu \mathrm{m}$ (Taylor and Chafetz, 2004).

Although crystals are located on both the top and bottom surfaces of the rafts, one surface is covered by significantly larger crystals, which is visible even with the naked eye (Fig. 5A, B). The surface in question has a spiky, serrated appearance, whereas the opposite side creates an impression of being more flat. This results in the asymmetrical appearance of the rafts. In spite of unknown orientation of the rafts during their growth, one can suppose that the spiky side was on the underside at that time.

The rafts with crystals on both their sides are different from the majority of the examples described to date. However, some similar examples exist. Folk et al. (1985, p. 360) mentioned rafts "lined by calcite crystals on both sides". Similar rafts, called double-sided rafts, were described from the Cayman Islands (Jones, 1989). Kostecka (1992) recognized rafts filling fissures in a travertine mound at Bešeňová (Slovakia) which were encrusted on their top and bottom surface.

Some rafts are composed of a few components cemented together and arranged subparallel (Fig. 5C). The component rafts do not adhere closely to each other. Similar but strongly cemented composite rafts were found in a palaeocave on Cayman Brac (Jones, 1989).

Sheets formed by microcrystalline calcite constitute flat cores of thin rafts (Fig. 5C-E). The detailed morphology of this microcrystalline calcite is not visible either in plane light or under SEM. The flat cores display dark colouration in plane light and reach up to $30 \mu \mathrm{m}$ in thickness. Their upper and lower surfaces are overgrown with calcite crystals. The long axes of the crystals are oriented mainly perpendicular to the flat core of the rafts. Only near the growing edges of the rafts do crystal orientations vary from perpendicular to almost parallel to the core. This concerns mainly the crystals developed on the bottom surfaces. The concentration of crystals along the growing edges of the rafts results in their substantial thickening in these zones. There, the crystal dimensions are larger, which is visible on both top and bottom surfaces (Fig. 5A, B). The largest elongated crystals exceed $3 \mathrm{~mm}$ in length. 

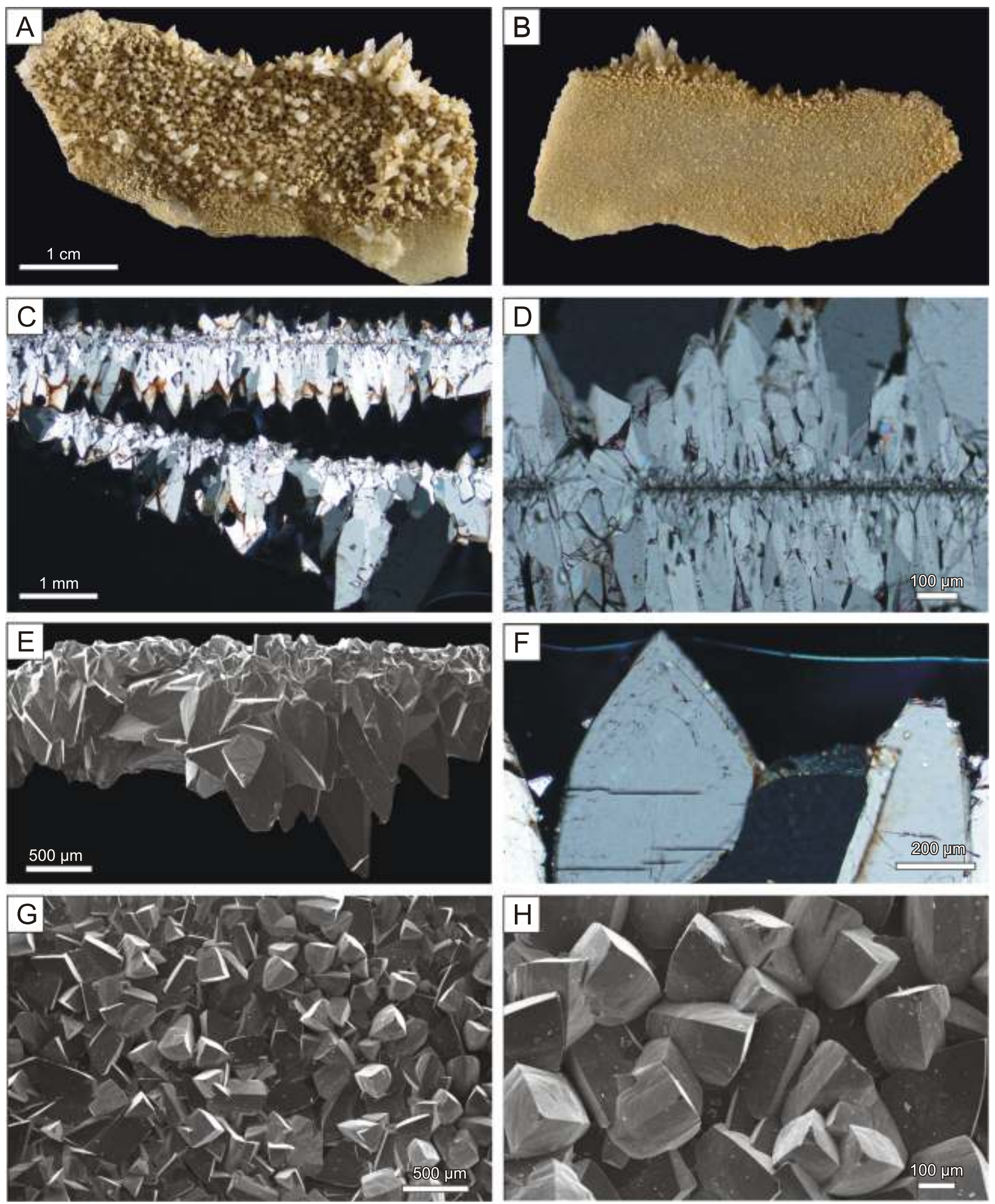

Fig. 5. Thin rafts

A - bottom surface, note the concentration of larger crystals along the primary edge, top of photograph (the same raft as in B); B - top surface covered with smaller crystals than bottom surface (the same raft as in A); $\mathbf{C}$ - cross-section through a thin raft composed of two component rafts with visible asymmetry of crystal sizes, transmitted light (crossed polars); D - cross-section of a raft with visible micritic core, zone of coalescence of two rafts is visible on the left-hand side, transmitted light (crossed polars); $\mathbf{E}$ - side view of a thin raft showing distinct asymmetry of crystal sizes (SEM image); $\mathbf{F}$ - gothic-arch calcite crystal with uniform extinction, top surface of a raft, transmitted light (crossed polars); $\mathbf{G}$ - high relief top surface of a raft composed of gothic-arch calcite crystals (SEM image); $\mathbf{H}$ - curved faces and edges of gothic-arch calcite crystals (SEM image) 
The crystals overgrowing microcrystalline cores of the rafts display variable morphology. Four types have been recognized: (1) smooth-faced rhombohedra, (2) single-stepped rhombohedra, (3) multistepped rhombohedra, and (4) macrotrilete crystals. They display uniform extinction.

Smooth-faced rhombohedra are a dominant form among crystals composing the rafts. They are located on both sides of the rafts; however, those located on the bottom surface are substantially larger (Fig. 5C, E). The rhombohedra display well-developed terminations. The interfacial angle in some smooth-faced rhombohedra, especially in those that are more elongated, abruptly changes near terminations. Such rhombohedra are terminated by an obtuse form.

Many of smooth-faced rhombohedra exhibit curved, convex up faces and edges (Fig. 5F-H). Those represent a variety of so called gothic-arch calcite. This term has been used in the literature to describe different type of crystals. It was originally coined by Folk et al. (1985) describing the bizarre types of calcites from Italian travertines. They stressed the curvature of faces in a gothic-arch pattern and the presence of a "mother" crystal with externally added slabs. Forms similar in shape were described under the name of gothic-arch calcite, for instance, by Janssen et al. (1999) from fossil Belgian tufa as well as by Rainey and Jones (2009) from stromatolites growing around hot springs on the eastern slope of the Rocky Mountains (Canada). Conversely, when describing calcite rafts from Bešeňová (Slovakia) and carbonates deposited from spring waters at Tylicz (Polish Outer Carpathians) Kostecka (1992, 1993) considered crystals fulfilling only the first criterion of Folk et al. (1985), that is with curved faces, as gothic-arch calcite. Similarly, gothic-arch calcites discussed by Chafetz and Guidry (2003) from Yellowstone travertine and by Gary and Sharp (2006) constituting subaqueous spar from La Pilita sinkhole (Mexico), lack additionally stacking slabs. The crystals described in the present paper are characterized only by curved faces and they lack additional slabs. Hence, they are similar to crystals from Bešeňová, Tylicz, La Pilita and Yellowstone. However, they differ from Tylicz crystals in extinction. The former display uniform extinction whereas the latter shows an undulose one.

Distinct macrosteps on faces distinguish single-stepped rhombohedra. They form horizontal ledges running across three crystal faces, hence engulfing crystals (Fig. 6A, B). The macrosteps are 2-3 $\mu \mathrm{m}$ wide (Fig. 6B). They are oriented approximately normal to crystal elongation, that is more or less parallel to the raft elongation. Interestingly, they are formed at the same elevation on the adjacent rhombohedra. Each crystal has only one macrostep on its walls. The parts of crystal faces located between terminations and macrosteps are smooth, whereas remaining parts, that is located below or over the steps, which depends on the location of a particular crystal on the bottom or top surface of rafts, display roughening. The rough surface is covered with randomly distributed convex irregularities, with the height reaching up to $1-2 \mu \mathrm{m}$ (Fig. 6B). The terminations of single-stepped rhombohedra are commonly blunt. Most of them are triangular in shape but some display a three-point star shape (Fig. 6A).

Multi-stepped rhombohedra are characterized by several steps being arranged parallel to each other (Fig. 6C). They are oriented oblique to crystal elongation and form an obtuse angle with the part of crystal edges which leads to the termination.
The occurrence of the steps results in a serrated appearance of crystal faces and edges. Some of the multi-stepped rhombohedra, besides oblique oriented steps, display a subtle horizontal step, similar to those typical of single-stepped rhombohedra (Fig. 6C). However, the latter is always less discernible. The terminations of multi-stepped rhombohedra are always blunt. They exhibit a triangular or three-point star shape.

Macrotrilete crystals are morphologically similar to trilete crystals described by Jones et al. (2005) from hot-spring deposits at Lýsuhóll (Iceland) and by Jones and Peng (2012) from Yunnan (China); however, they are two orders of magnitude larger. Hence, they are named macrotrilete crystals. The macro-trilete crystals are up to $3 \mathrm{~mm}$ high. They are located mostly near the edges of the rafts and oriented at different angles to raft elongation. Due to their concentration, the raft edge has a thorny appearance (Fig. 5A, B). They also formed on fissure walls just beneath the water table (Fig. 4).

Each macrotrilete crystal is composed of three arms radiating from a central axis. The arms are regularly arranged at an angle of $120^{\circ}$ and have almost similar dimensions. The arms thin from the central axis towards their flanks. Thus, in cross-section normal to the axis the macrotrilete crystal forms a regular three-point star (Fig. 6D). In a view oblique to the central axis, two arms display clear steps arranged at an angle of around $30^{\circ}$ with the central axis (Fig. 6E, F). The steps ascending from the axis resemble tree-branches ascending from a trunk. The steps have a slightly concave-down shape and divide each arm into subcrystals arranged one over another. Generally, the whole crystal thins upwards; however, its edges are serrated, which results from the occurrence of subcrystals (Fig. 6E). Moreover, in some cases subcrystals have a spiky termination protruding upwards. Most of the macrotrilete crystals have blunt terminations in the shape of tree-point star.

Macrotrilete crystals can be regarded as crystals with incomplete faces. This implies that their edges grew faster than their faces. Thus, they represent a category of skeletal crystals (sensu Gornitz and Schreiber, 1981; Southgate, 1982). Similar skeletal crystals with partly developed faces were detected in recent travertines near Durango (Chafetz et al., 1991, fig. 12A).

Thin rafts originally formed at the air-water interface (Hill and Forti, 1997). There, the initial form of rafts is a thin film of calcite crystals floating on the water surface. These forms are incorporated within the thin rafts studied and are still visible as their cores (Fig. 5C, D). Calm water and ideally a still air-water interface create a favourable environment for creation of the initial form of the rafts. Thus, the water table in the fissures, where the rafts described were formed, must have been completely stagnant and, hence, the supply of dripping or seeping water, if any, must have been strictly limited. It seems probable that relatively narrow fissures provide a low energy environment where rafts do not sink immediately by drips or drying up of the water bodies. Based on modern examples from caves and hot springs the time of formation of initial rafts can be estimated at a period of minutes to months, depending on the chemistry of the parent water. In a hot-spring travertine system, where water supersaturation with respect to carbonate minerals is extremely high, rafts are formed within a few minutes (Chafetz et al., 1991). Conversely, the formation of rafts in caves seems to be slower. Taylor and Chafetz, (2004) observed rafts precipitated from cave water in times shorter than three months. 

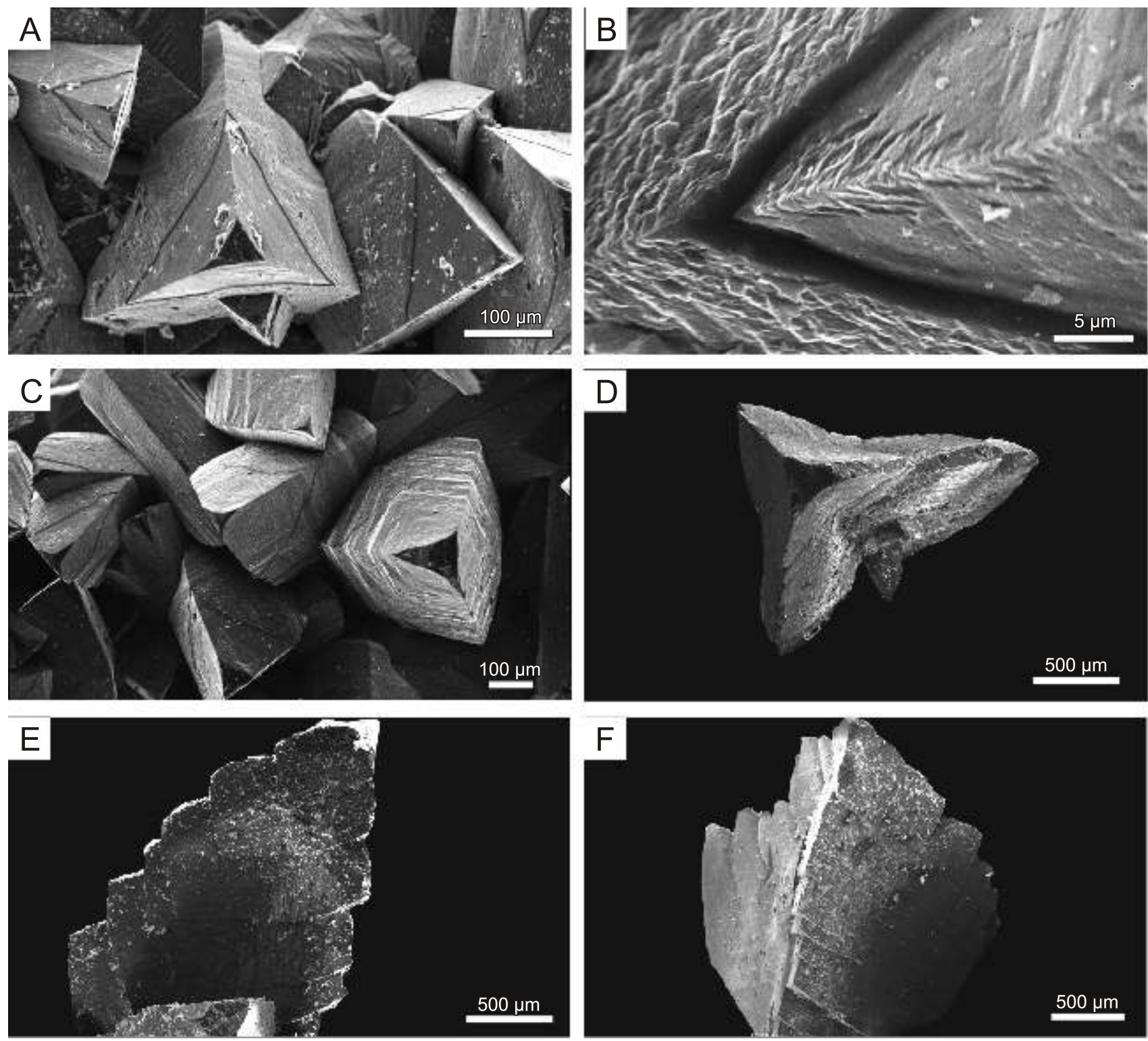

Fig. 6. Thin rafts

A - single-stepped rhombohedra with ledges engulfing their tops, the face part over a step is smooth in contrast to the rough part located below a step, note triangular shape and three-point star-shaped crystal terminations (SEM image); B - detail view of a step, note contrast of the relief between lower and upper part of crystal faces (SEM image); C - multi-stepped rhombohedra with three-point star-shaped terminations (SEM image); D - macrotrilete crystal, top view (SEM image); E, F - macrotrilete crystals, side view (SEM images)

The initial raft can float due to surface tension (Folk et al., 1985; Hill and Forti, 1997) and, in some cases, additionally by the buoyancy of entrapped gas bubbles (Taylor and Chafetz, 2004). However, they were subsequently overgrown by calcite, which resulted in exceeding the threshold of their buoyancy and, in consequence, in gravitational sinking of the rafts. Although the thin rafts from Klęczany are relatively fine structures, even they are definitely too heavy to be freely floating objects. Thus, they only commenced to grow as initial floating rafts. Subsequently, they were attached to fissure walls and were partly or completely submerged due to the fluctuation of water table. This is shown by the location of crystals on both sides of the rafts visible in all the samples studied. Later, probably during quarrying, the rafts were broken and deposited at fissure bottoms as loose fragments.
MASSIVE RAFTS

The massive rafts are built of closely spaced calcite rhombohedra. Their thickness varies from 2 to $14 \mathrm{~mm}$. They are flat or only slightly curved. The massive rafts are either cemented to fissure walls or rest one upon another on fissure bottoms (Figs. 7 and 8A). In the latter case they constitute a pile comprising up to more than ten individual rafts. Within a pile, neighbouring rafts adhere to each other, but they are only weakly cemented. Hence, the piles disintegrate easily into individual rafts. The rafts constituting a pile are oriented parallel or subparallel (Fig. 8A).

The rafts cemented to fissure walls can link opposite walls thus forming spectacular bridge or ladder structures (Fig. 7A; see also Kostecka, 1992). Most of them are oriented horizontally; however, some display oblique orientation. The empty space between the rafts reaches $2 \mathrm{~mm}$ in height. 

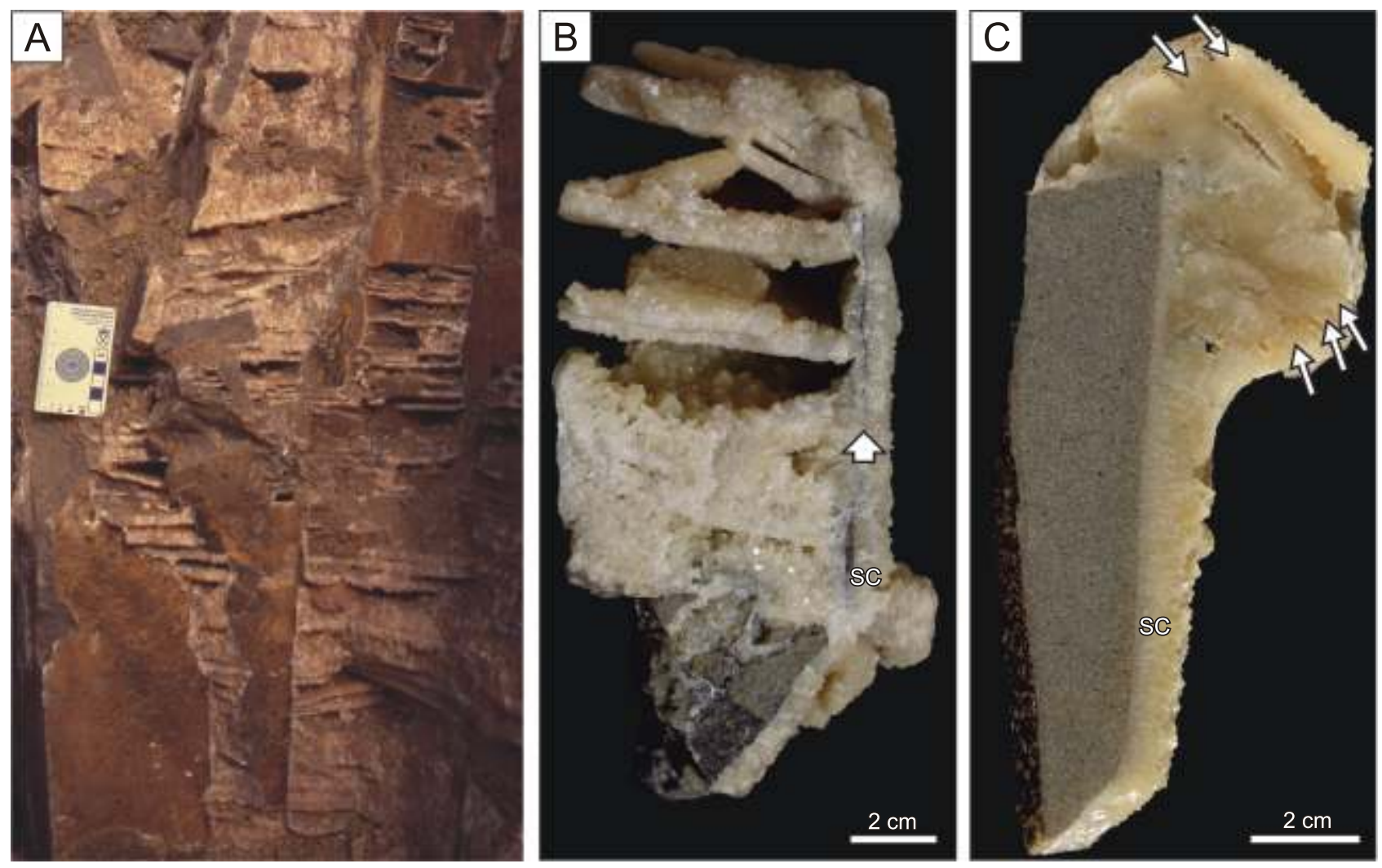

Fig. 7. Massive rafts

A - cemented to fissure walls forming bridge structures in a small fissure, field photograph; $\mathbf{B}$ - group of massive rafts cemented to the extremely thin wall (arrow), dividing two fissures, another side of a wall is covered with sparry crusts (SC); C - sparry crusts (SC) with cemented massive rafts (arrows), cross-section

The thickness of crystal layers constituting both sides of a particular raft is different, which results in subtle asymmetry of a raft. However, there is no constant tendency in the asymmetry. This means that the top side is thicker in some rafts, whereas the bottom side is thicker in the others.

Crystals forming massive rafts grow upwards and downwards from a micritic central core, similarly to those in thin rafts (Fig. 8B, C). The width of crystals increases and their optic orientation becomes more uniform downwards and upwards from the central core. Also the amount of crystals clearly decreases in these directions. The crystals are tightly packed; empty spaces between them are limited to the outer parts of the rafts (Fig. 8C, D). No internal lamination is detected within the crystals.

The crystals show well developed rhombic terminations. Many of them represent gothic-arch calcite with curved faces and edges (Fig. 8D, E). The faces of gothic-arch calcite are overgrown with smaller "daughter" crystals growing away from the face and having different optic orientations. "Daughter" crystals have three faces (Fig. 8D, E). Some of them also display gothic-arch calcite character. Apart from three-faced "daughters", the faces of some larger crystals are overgrown with thin platy crystal slabs (Fig. 8E).

Some pores between terminations of adjacent crystals in massive rafts are filled with silt-sized crystal debris (Fig. 8F). The crystals are broken, some of them are elongated. They reach $40 \mu \mathrm{m}$ across. They are loosely packed, with no sorting.

The exceptionally thick massive rafts commenced to grow at the air-water interface, as thin rafts. Subsequently, they become stabilized at a fissure wall. After a shift of water level in- dividual rafts were overgrown by calcite on their top and bottom surface. Hence, the rafts developed from fine, friable entities to robust ones of substantial thickness. Small changes of water table caused the formation of ladder structures composed of many parallel oriented rafts.

Fine-grained crystal silt accumulated between sparry crystals forming the massive rafts. They most probably originated as debris from disintegrated sunken thin rafts. Raft debris has been recognized in travertines (Guo and Ridinig, 1998) as well as in caves, including littoral ones (Hill and Forti, 1997; Csoma et al., 2006; Fornós et al., 2009; van Hengstum et al., 2011). The debris is probably an analogue to vadose silt described by Dunham (1969) as an indicator of emersion of shallow marine deposits.

There are several factors influencing the growth of exceptionally thick rafts. The development of rafts in narrow fissures seems to allow them to stabilize before sinking. Subtle changes of water table resulted in the long-lasting location of rafts cemented to fissure walls in zone of active precipitation, that is only several meters beneath the water table (Ford, 1989). The chemistry of the parent water is obviously of crucial significance to the development of exceptionally thick rafts. Rafts of similar thickness were described from fissures within a travertine mound at Bešeňová (Slovakia), and from some caves in Budapest (Hungary). In the former case they constitute calcite veins (Kostecka, 1992), whereas in the latter one their origin can be associated with ascending thermal water (Müller, 1989, fig. 2-67). In both examples described above water seems to have been highly saturated with respect to calcium carbonate, which also had to take place in the case of Klęczany. 

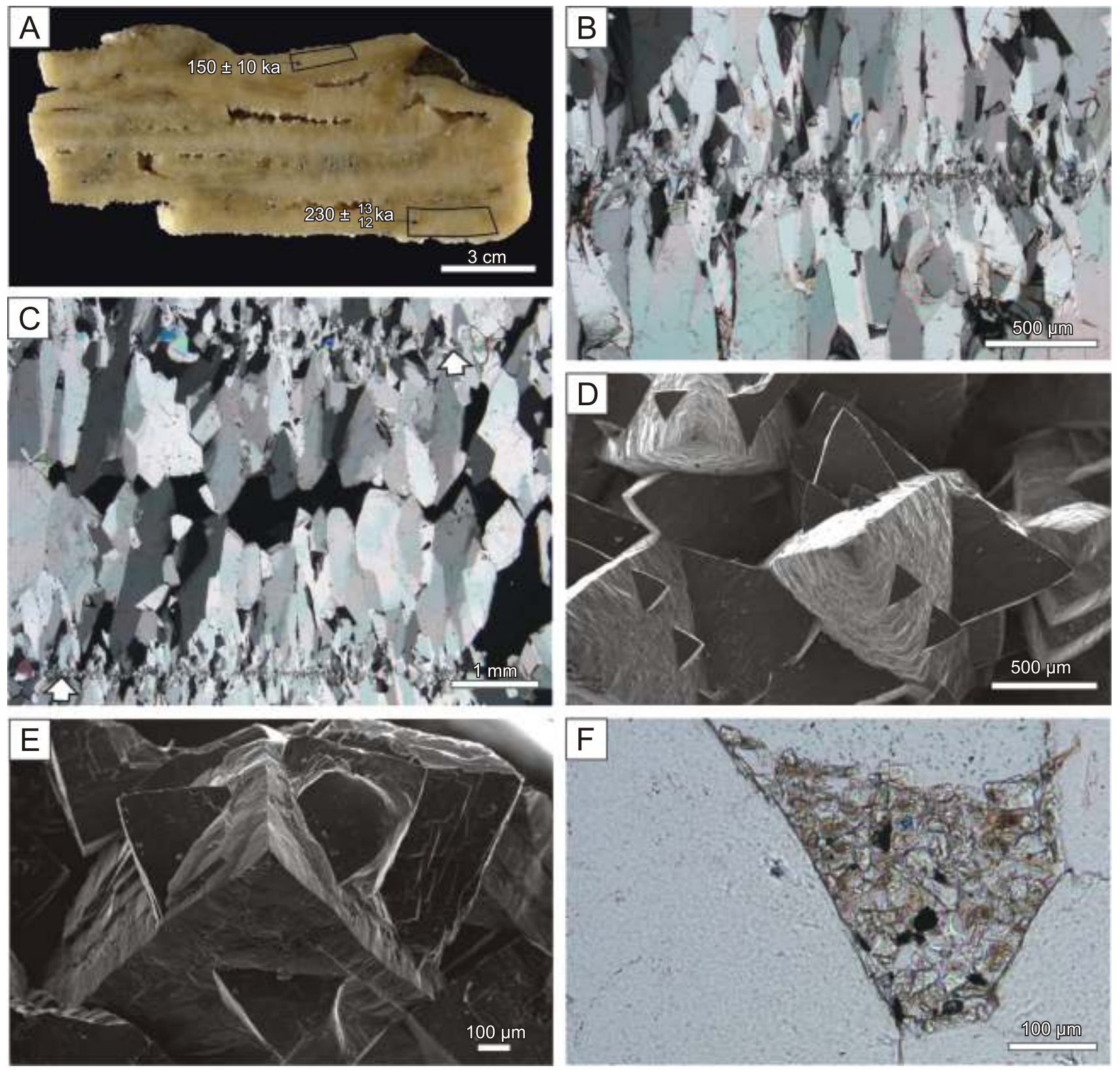

Fig. 8. Massive rafts

A - pile of massive rafts, position of dated samples and their ages are shown; $\mathbf{B}$ - cross-section of a raft with visible micritic core, note growth direction of crystals up and down from the core, transmitted light (crossed polars); $\mathbf{C}$ - two cemented massive rafts forming a pile, porosity is preserved between the rafts, cores of the rafts are arrowed, transmitted light (crossed polars); D - gothic-arch calcite crystals with rough surfaces overgrown with three-face "daughter" crystals (SEM image); E - gothic-arch calcite crystals overgrown with three-face "daughter" crystals and flat crystal slabs (SEM image); F crystal silt accumulated in intercrystalline pore within a massive raft, transmitted light

\section{SPARRY CRUSTS}

Besides the vadose speleothems and rafts described above several types of sparry crusts were recognized in specimens collected in the Klęczany Quarry. They include: (1) thin sparry crusts, (2) mammillary sparry crusts, and (3) porous sparry crusts. All crusts are devoid of internal lamination typical of vadose flowstones.

Thin sparry crusts form compact layers very light gray to very pale orange in colour which line the walls of fissures and cement calcareous sandstone debris that partly fill some fissures (Fig. 7B, C). They are spatially integrated with massive rafts. Fissure walls, to which the massive rafts are cemented, are always coated with thin crusts. Some crusts of this type cement calcareous sandstone debris. Small clumps of cemented residual material have been recognized in one thin sparry crust examined. The clumps are up to $1.1 \mathrm{~mm}$ across (Fig. 9C). The thickness of thin crusts ranges from 2 to $19 \mathrm{~mm}$. They are composed of elongated calcite crystals growing outwards from the substrate (Fig. 9A). The length of the largest crystals equals the thickness of a spar layer. The crystals are tightly packed. They nucleated on fissure walls and display competitive growth (sensu González et al., 1992), impingement crystallization patterns (sensu Dickson, 1993) or geometric selection (sensu Self and Hill, 2003). Neither internal lamination nor additional nucleation surfaces (e.g., corrosion surfaces) are present within thin crust. The crystals show well-developed rhombohedral terminations with small slabs adhering to crystal faces (Fig. 9B). 

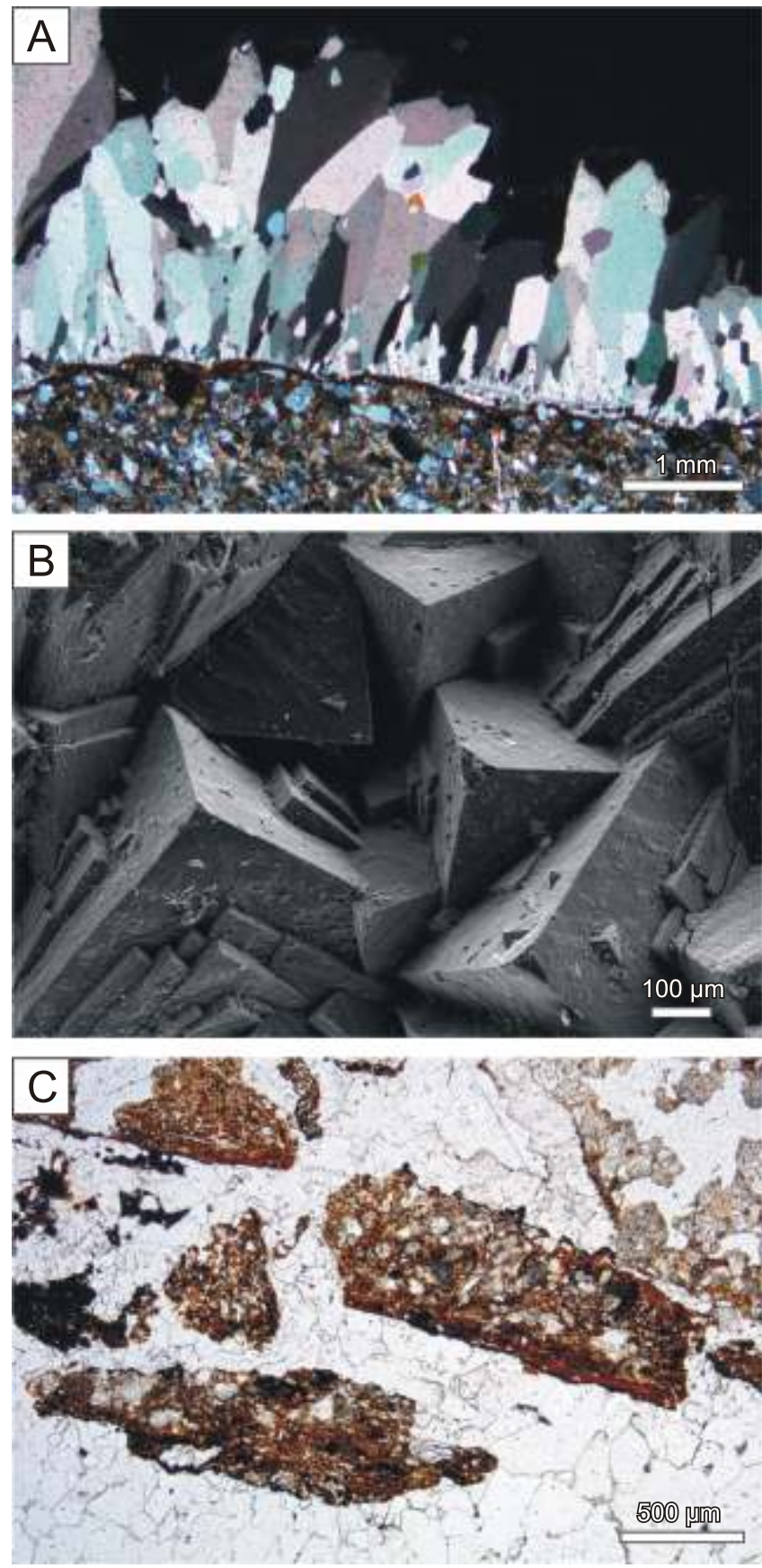

Fig. 9. Thin sparry crusts

A - sparry crystals growing out of a fissure wall, transmitted light (crossed polars); B - calcite crystals with slightly curved faces overgrown with flat crystal slabs (SEM image); C - irregular clumps of residual siliciclastic material introduced into a thin sparry crust, transmitted light

Mammillary sparry crusts are honey-coloured and semitranslucent and reach up to $25 \mathrm{~mm}$ thick (Fig. 10A, B). They are compact, lack intercrystalline porosity, and display internal banding which is shown by changes in colour intensity. They line the fissure walls and cement calcareous sandstone debris. The direct spatial relationship between mammillary sparry crusts and other types of calcite speleothems is not clear. The only evidence comprises thin rafts in the centres of some crusts. In this case the rafts served as a nucleation surface for a crust (Fig. 10A).

The upper surface of the crusts is knobbly. Individual oval knobs, up to $3 \mathrm{~cm}$ across, are surrounded by depressions. The
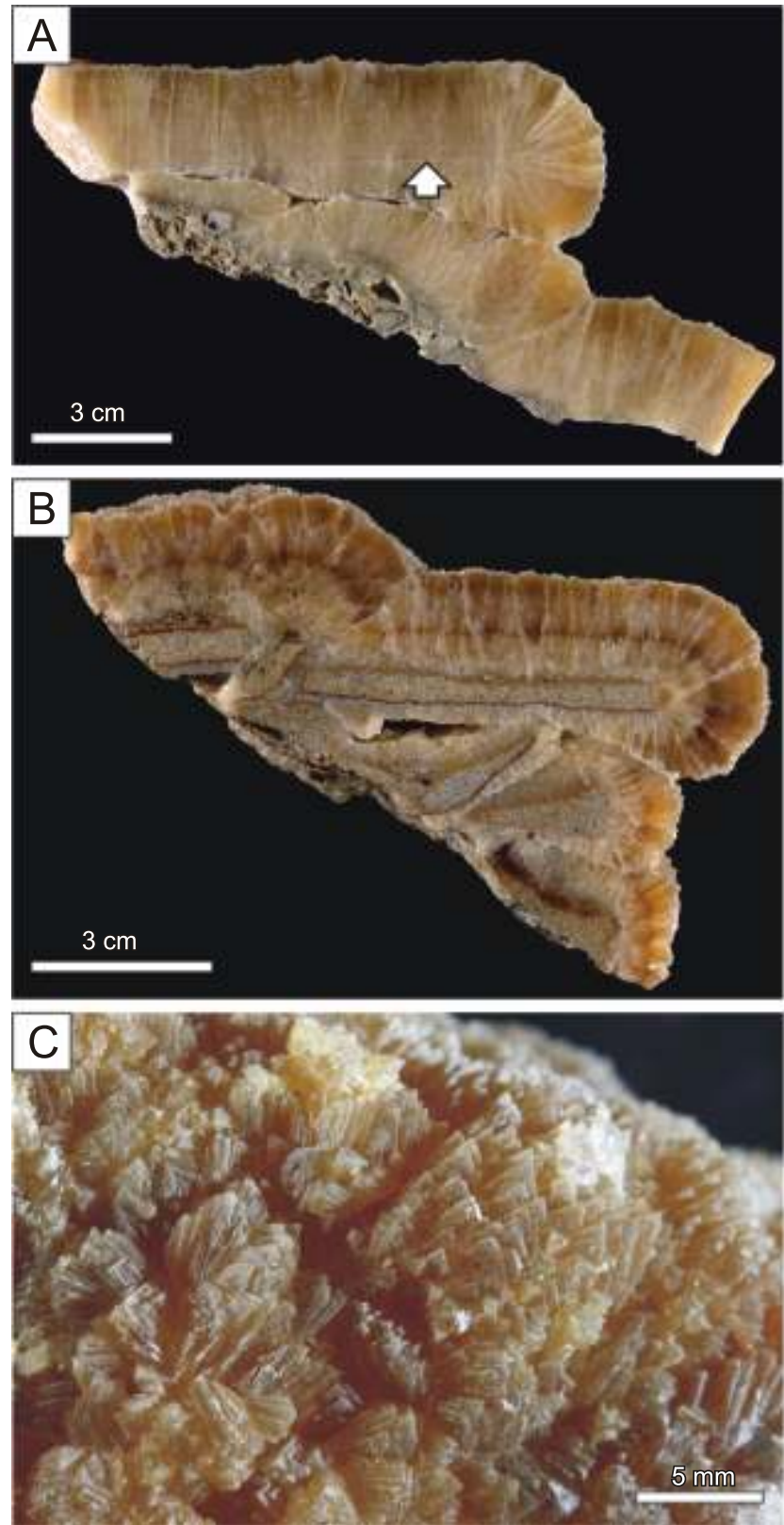

Fig. 10. Mammillary sparry crusts

$\mathbf{A}$ - thin raft acting as a nucleation surface for a crust (arrow), cross-section; $\mathbf{B}$ - crusts cementing sandstone debris, cross-section; $\mathbf{C}$ - surface of a crust composed of roof-tile style arranged crystal terminations

whole surface is built of crystal slabs arranged in a roof-tile style at the millimetre scale (Fig. 10C). The similarly oriented slabs form domains which, in turn, compose the knobs. The roof-tile style of arrangement is strikingly similar to that described and illustrated by Folk et al. (1985, fig. 7e, f) from Italian travertine and ascribed by those authors to gothic-arch calcite. However, two essential differences exist. Firstly, in the Italian examples the slabs are up to $0.02 \mathrm{~mm}$, whereas in Klęczany they reach a length of $2 \mathrm{~mm}$ long. Secondly, the slabs described do not exhibit distinct curvature of edges, as is the case in the gothic-arch calcite of Folk et al. (1985).

The crystals are organized in radiating fans, which is visible in thin section parallel to crust thickness (Fig. 11A). The fans comprise up to 30 crystals. Both the fans and individual crystals widen upwards from the substrate. The former reach a width of 
$1.2 \mathrm{~mm}$ at their top whereas the latter are between 0.2 and $0.5 \mathrm{~mm}$ across at the topmost parts of the fans. The highest fans spread from the substrate to the top of the crust. Boundaries between juxtaposed fans are of compromise type (Fig. 11B). Some fans are eliminated by neighbouring ones. The optic orientation of neighbouring crystals within one fan is slightly different, which causes the undulose extinction of a particular fan (Fig. 11A, B). The crystal terminations are markedly asymmetrical in dimensions of particular faces (Fig. 11C, D). The angle between the crystal faces equals $80-120^{\circ}$.

The observations made on sections cut normal to the elongation of crystals reveals their unusual habit and arrangements. The fans are composed of triarmed crystals, each being built of three arms arranged at an angle of $120^{\circ}$ and linked in a central point (Fig. 12A). All three arms form one crystal having uniform optical orientation. The arms of one crystal have straight parallel boundaries with kinks forming an obtuse angle of $120^{\circ}$. Although the thickness of a particular arm decreases systematically outwards from the central point, owing to several kinks, the arm boundaries are parallel to each other and parallel to arm elongation. The shape of arms is the main difference between the triarmed crystals and trilete ones building the thin rafts. However, affinity between those types of crystals seems very probable.
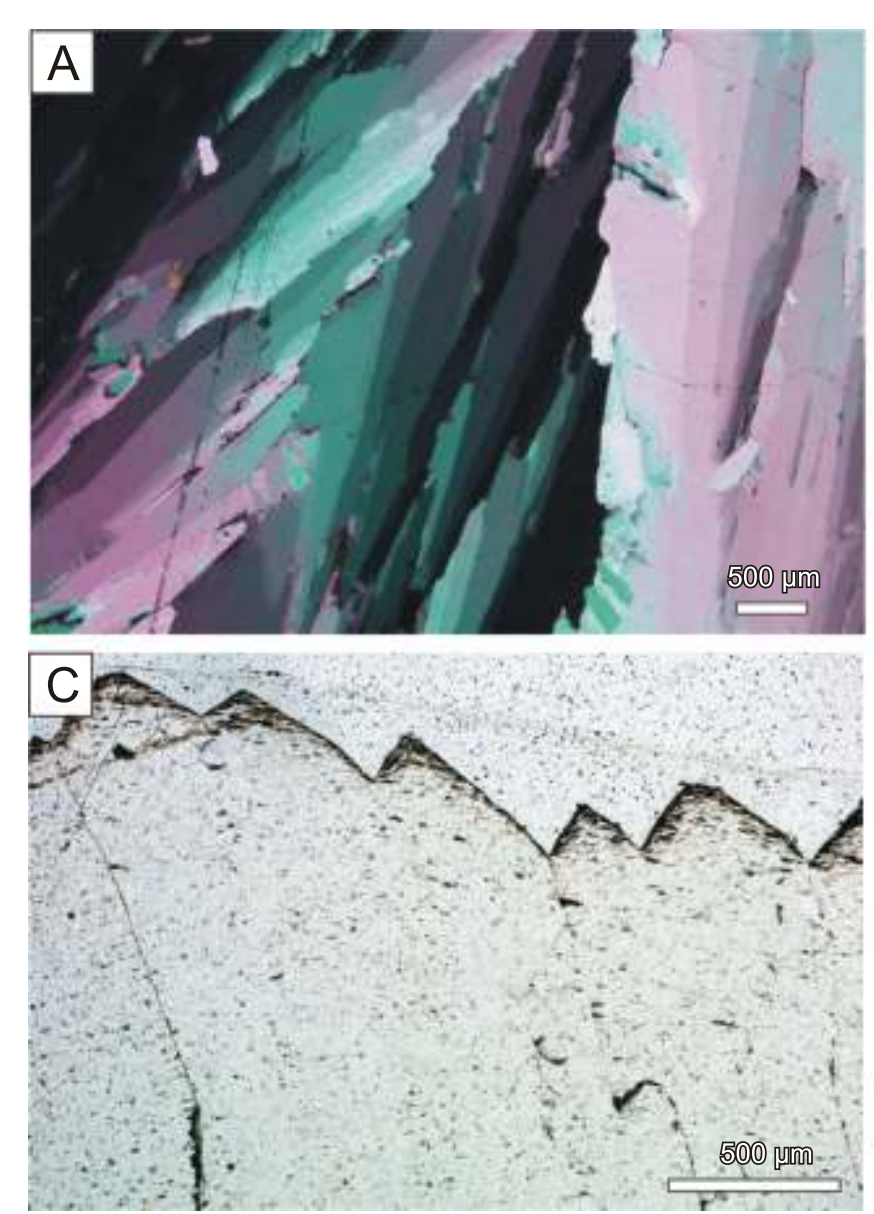

Each triarmed crystal is engulfed by crystals displaying rectangular cross-sections or crystals being incomplete triarmed ones, that is composed of only two arms (Fig. 12A, B). The optic orientation of adjacent crystals is different. The crystals are tightly-packed hence intercrystalline boundaries between them are scarcely visible in plane polarized light (Fig. 12C). One triarmed crystal together with engulfing crystals forms one domain, the boundary of which is, conversely, clearly visible in plane polarized light. Some domains include more than one triarmed crystal; however, in this case the optic orientation of these crystals is identical. Most probably each domain represents one fan visible in a section parallel to crystal elongation. Strikingly, the crystals in neighbouring domains are elongated in the same, or almost the same direction. However, they have different optic orientations.

Porous sparry crusts are up to $5.5 \mathrm{~cm}$ thick (Fig. 13A). They are pale yellowish orange in colour. Such crusts grew on fissure walls. The crystals that compose this type of crust are organized in domains generally triangular or rectangular in outline and exceeding $1 \mathrm{~cm}$ across, which are clearly visible on the crust surface (Fig. 13B). Each domain is composed of loosely cemented crystals. Intercrystalline pores exist between neighbouring crystals within one domain and between neighbouring domains. The porous zone of the crust is $1.5 \mathrm{~cm}$ thick below the
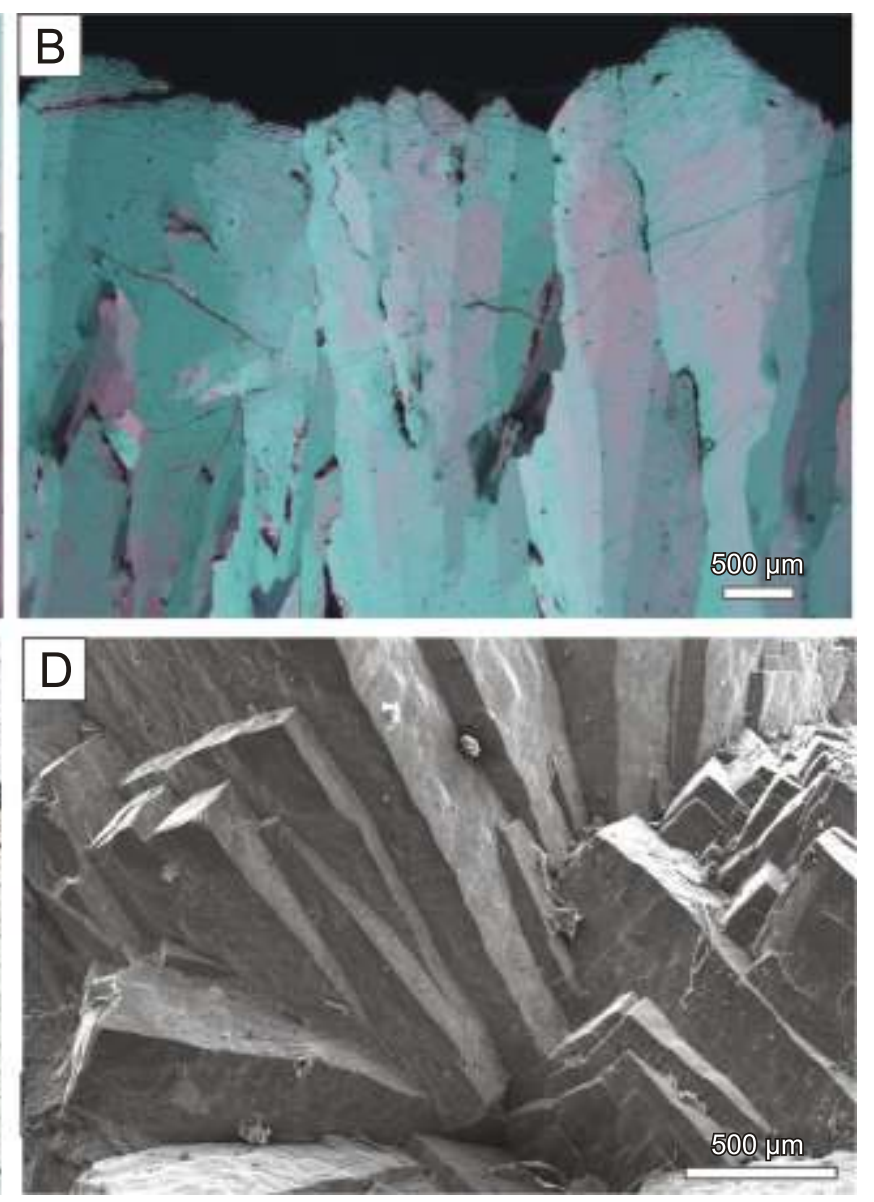

Fig. 11. Mammillary sparry crusts

A - crystal fans forming a crust, transmitted light (crossed polars); B - relatively wide crystal in a fan top in comparison to their lower parts (see A), note more uniform optic orientation of crystals forming one fan and undulose extinction of the fan, transmitted light (crossed polars); $\mathbf{C}$ - top part of a fan, note asymmetrical crystal terminations, transmitted light; D - crystal terminations under SEM 

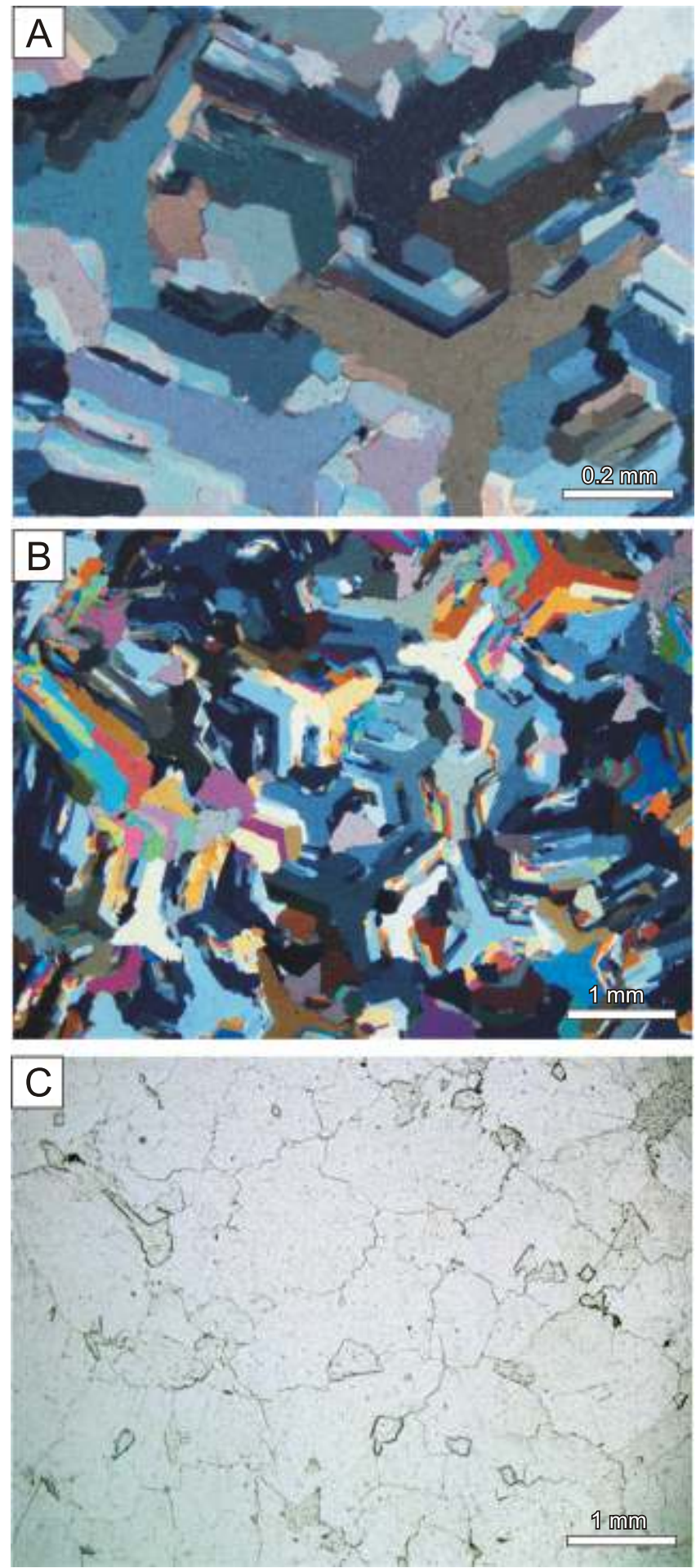

Fig. 12. Triarmed crystals composing a mammillary sparry crust seen in cross-section perpendicular to crystal elongation

A - complete triarmed crystals with arms arranged at an angle of $120^{\circ} \mathrm{en}-$ gulfed by incomplete triarmed crystals having only two arms and by crystals rectangular in cross-section, transmitted light (crossed polars); B densely packed triarmed crystals forming domains, elongation of crysta arms in neighbouring domains is similar although their optic orientation is different, transmitted light (crossed polars); C - intercrystalline bound aries within a single domain are invisible, in contrast to domain boundaries, transmitted light, equivalent of Figure 12B crust surface. Deeper, the crusts are more compact; however, some intercrystalline pores occur (Fig. 13A).

The porous sparry crusts are composed predominantly of relatively large, robust, rhombohedral crystals, exceeding $1 \mathrm{~mm}$ across. The small crystal slabs adhere to faces of large rhombohedra (Fig. 13C). Moreover, the faces of robust rhombohedra are also overgrown with three-faced small rhombohedra. They are patchily distributed and are characterized by different optic orientations. Triarmed crystals occur subordinately within porous sparry crusts. They are incorporated within rhombohedral crystals. Crystal silt, up to $0.1 \mathrm{~mm}$ across, fills some intercrystalline pores. Some crystals bear irregularly distributed microcrystalline spots, that probably resulted from corrosion (Fig. 13D).

Several lines of evidence suggest that sparry crusts formed below the water table, that is in phreatic conditions. These are as follows: (1) acute crystal terminations with relatively high relief, (2) occurrence as lining upon all surfaces - that is fissure walls and calcareous sandstone debris, (3) almost constant thickness of the crusts over long distances, (4) lack of any traces of vadose relief as for instance rimstone pools, crenulations, stalactites (5) co-occurrence with massive rafts which formed finally below the water table, (6) lack of distinct internal lamination and traces of corrosion, which are typical of vadose speleothems, and (7) incorporation of sunken thin calcite rafts and debris formed due to disintegration of such rafts.

Similar calcite sparry crusts, also called phreatic calcite or calcite spar, are known from caves all around the world (Hill and Forti, 1997). They develop in shallow phreatic conditions (Ford et al., 1993; Dublyansky, 2000). Their growth rate is low; for instance Ford (1989), based on dating results, estimated the growth rate of subaqueous crusts in Wind Cave (USA) at $\sim 0.15 \mathrm{~mm}$ per 1000 years.

The precise spatial relationship between each type of sparry crust distinguished is unknown. Hence, it is not clear which factors influenced the origin of a particular type of sparry crust.

\section{${ }^{230} \mathrm{Th} / \mathrm{U}$ AGES}

The uranium content and ${ }^{234} \mathrm{U} /{ }^{238} \mathrm{U}$ activity ratios in all samples analysed are at the levels typical of speleothems (Table 1). Spectra obtained were clear and peaks of $U$ and Th isotopes were well-separated.

Two analyses of sample KL 7 (lab. no. W 1370 and $\mathrm{W}$ 1441) have given unacceptable results. ${ }^{230} \mathrm{Th} /{ }^{234} \mathrm{U}$ activity ratios are higher than values existing in nature (1.9 and 2.5). In no sample has significant detrital contamination been detected $\left({ }^{230} \mathrm{Th} /{ }^{232} \mathrm{Th}\right.$ activity ratios at the level of 34 and 460 , respectively). Apparently the system was not closed with respect to uranium and thorium. The ${ }^{234} \mathrm{U} /{ }^{238} \mathrm{U}$ activity ratio and uranium content are slightly lower than in other samples. Because uranium is much more easily mobilized than thorium (Ivanovich and Harmon, 1992; Bourdon et al., 2003) secondary leaching of uranium, with preferential leaching of ${ }^{234} \mathrm{U}$, cannot be excluded. Microscopic studies of thin sections from sample KL 7 show traces of corrosion (Fig. 13D). These traces may reflect the same process which resulted in the opening of the system for isotope migration. 

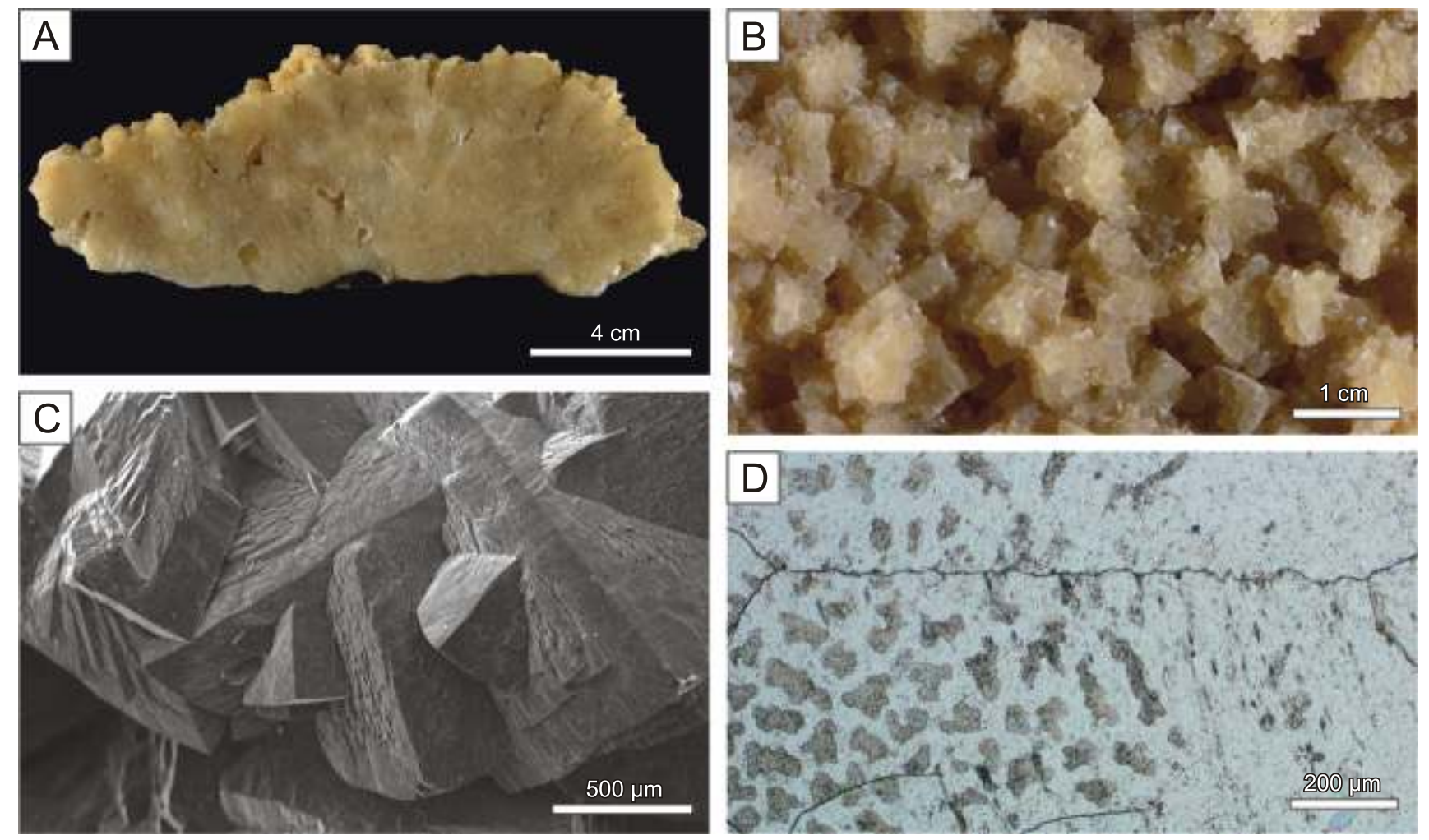

Fig. 13. Porous sparry crusts

A - cross-section of a crust showing intercrystalline porosity; $\mathbf{B}$ - surface of a crust with domains comprising several crystals; $\mathbf{C}$ - rhombohedral calcite crystals overgrown with three-face "daughter" crystals and flat crystal slabs (SEM image); D - traces of microcorossion within sparry crystals forming a crust

Ta b l e 1

${ }^{230} \mathrm{Th} / \mathrm{U}$ isotopic data used for dating of Klęczany speleothems

\begin{tabular}{|l|c|c|c|c|c|c|c|c|}
\hline Sample & Lab. no. & Speleothem type & $\begin{array}{c}\text { U cont. } \\
{[\mathrm{ppm}]}\end{array}$ & ${ }^{234} \mathrm{U} /{ }^{238} \mathrm{U}$ & ${ }^{230} \mathrm{Th} /{ }^{234} \mathrm{U}$ & ${ }^{230} \mathrm{Th} /{ }^{232} \mathrm{Th}$ & $\begin{array}{c}\text { Age } \\
{[\mathrm{ka}]}\end{array}$ & Comment \\
\hline KL 1 & W 2890 & thin raft & $0.143 \pm 0.005$ & $1.57 \pm 0.06$ & $0.28 \pm 0.02$ & $>1000$ & $35 \pm 2$ & \\
\hline KL 3 & W 2891 & massive raft & $0.30 \pm 0.01$ & $1.67 \pm 0.06$ & $0.95 \pm 0.03$ & $615 \pm 306$ & $215_{-13}^{+14}$ & \\
\hline K1 7 & W 1370 & porous sparry crust & $0.25 \pm 0.01$ & $1.20 \pm 0.04$ & $1.86 \pm 0.06$ & $34 \pm 4$ & & open system \\
\hline K1 7 & W 1441 & porous sparry crust & $0.26 \pm 0.02$ & $1.22 \pm 0.07$ & $2.5 \pm 0.2$ & $460 \pm 240$ & & open system \\
\hline K1 11 & W 1372 & massive raft & $0.67 \pm 0.02$ & $1.69 \pm 0.03$ & $0.217 \pm 0.006$ & $>1000$ & $26.2 \pm 0.8$ & \\
\hline K1 11 & W 1441 & massive raft & $0.42 \pm 0.02$ & $1.69 \pm 0.07$ & $0.85 \pm 0.03$ & $274 \pm 133$ & $170 \pm 12$ & \\
\hline KL 11-1 & W 2888 & massive raft & $0.44 \pm 0.02$ & $1.82 \pm 0.08$ & $0.80 \pm 0.03$ & $118 \pm 61$ & $150 \pm 10$ & \\
\hline KL 11-2 & W 2889 & massive raft & $0.238 \pm 0.006$ & $1.78 \pm 0.05$ & $0.98 \pm 0.02$ & $>1000$ & $230_{-12}^{+13}$ & \\
\hline K1 13 & W 1371 & mammillary sparry crust & $0.56 \pm 0.02$ & $1.70 \pm 0.04$ & $0.253 \pm 0.007$ & $486 \pm 352$ & $31.0 \pm 0.9$ & \\
\hline KL 5 & W 2892 & flowstone & $0.308 \pm 0.007$ & $1.57 \pm 0.05$ & $0.57 \pm 0.02$ & $34 \pm 5$ & $86 \pm 4$ & \\
\hline KL 16 & W 2893 & flowstone & $0.204 \pm 0.006$ & $1.51 \pm 0.05$ & $0.088 \pm 0.007$ & $24 \pm 9$ & $10.0 \pm 0.8$ & \\
\hline
\end{tabular}



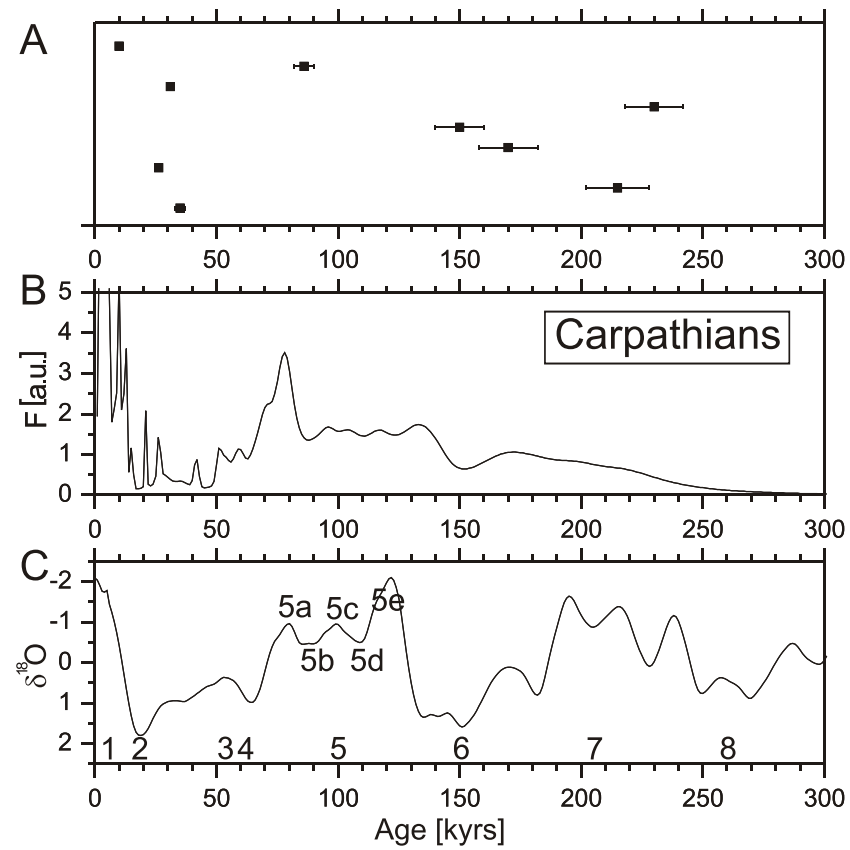

Fig. 14

A - Th/U dates of calcites from the Klęczany Quarry; B - crystallization growth frequency of speleothems from Carpathian caves after Hercman (2000); C - stacked, smoothed oxygen-isotope record as function of age after Imbrie et al. (1984), MISs are numbered

Analytical results are given in Table 1 and in Figures 3A, B, $8 \mathrm{~A}$ and 14. All the speleothems studied but one are Pleistocene in age. The youngest sample grew in the early Holocene. No correlation between the petrography of the speleothems and their age has been observed.

\section{STABLE ISOTOPE COMPOSITION}

The stable isotope compositions of the carbonate samples are shown in Table 2 and presented in Figure 15. Except for sample 13 all other analytical data form two clusters of points. The first of these is characterized by $\delta^{18} \mathrm{O}$ values between -9.8 and $-8.5 \%$. Values of $\delta^{13} \mathrm{C}$ fall in the range between -5.7 and $-0.6 \%$ o. Except for one, all samples belonging to this group formed in phreatic conditions; they represent sparry crusts and massive rafts. The range of oxygen isotope composition of the second group of samples is between -9.4 and $-7.3 \%$. This is determined by samples 5a and 5e taken from the same specimen. Excluding samples no. 5a and 5e the variability of $\delta^{18} \mathrm{O}$ values is reduced to the range from -8.6 to $-7.5 \%$. Values of $\delta^{13} \mathrm{C}$ are within a relatively narrow range: from -11.5 to $-9.7 \%$. Most samples belonging to the second cluster formed either at the air-water interface or on the fissure walls above the water table. Only two of them - 5f and $22 \mathrm{~b}$ - precipitated below the water table. However, sample $22 \mathrm{~b}$ formed at a distance of centimetres below the water table, and so in conditions very similar to those of thin rafts.

The oxygen isotope composition of sample 13 taken from a mammillary sparry crust is identical to that of sample $5 \mathrm{e}$, but their $\delta^{13} \mathrm{C}$ values are more positive by about $2-3 \%$.

Table 2

Stable isotopic composition of selected speleothem samples

\begin{tabular}{|c|c|c|c|}
\hline Sample & Type of speleothem & $\begin{array}{c}\delta^{18} \mathrm{O} \\
{[\% \circ \mathrm{VPDB}]}\end{array}$ & $\begin{array}{c}\delta^{13} \mathrm{C} \\
{[\% \circ \mathrm{VPDB}]}\end{array}$ \\
\hline KL 1.1 & thin raft & -8.48 & -11.20 \\
\hline KL 1.2 & thin raft & -8.61 & -11.18 \\
\hline Kl 1a & thin raft & -8.38 & -11.34 \\
\hline $\mathrm{K} 12 \mathrm{a}$ & thin raft & -8.42 & -11.13 \\
\hline $\mathrm{K} 12 \mathrm{~b}$ & thin raft & -8.43 & -11.17 \\
\hline K1 5a & flowstone & -9.43 & -10.91 \\
\hline $\mathrm{K} 15 \mathrm{~b}$ & flowstone & -8.80 & -10.72 \\
\hline K1 5c & flowstone & -8.75 & -10.87 \\
\hline $\mathrm{K} 15 \mathrm{~d}$ & flowstone & -8.75 & -9.76 \\
\hline K1 5e & flowstone & -7.29 & -10.62 \\
\hline $\mathrm{K} 15 \mathrm{f}$ & thin sparry crust & -7.87 & -11.72 \\
\hline KL 7.1 & porous sparry crust & -9.15 & -1.29 \\
\hline KL 7.2 & porous sparry crust & -8.98 & $-1,93$ \\
\hline KL 11.1 & massive raft & -9.46 & -3.56 \\
\hline K1 11a & massive rafts & -9.64 & -3.37 \\
\hline $\mathrm{K} 111 \mathrm{~b}$ & massive rafts & -8.56 & -3.98 \\
\hline $\mathrm{K} 111 \mathrm{c}$ & massive rafts & -8.64 & -4.25 \\
\hline KL 13.1 & mammillary sparry crust & -7.28 & -8.25 \\
\hline KL 13.2 & mammillary sparry crust & -7.27 & -7.48 \\
\hline Kl 14 & flowstone & -7.79 & -10.92 \\
\hline Kl 15 & flowstone & -7.96 & -11.48 \\
\hline KL 16 & flowstone & -7.49 & -10.72 \\
\hline KL 7.1 & calcite vein in basement rock & -9.83 & -0.60 \\
\hline KL 17.2 & massive raft & -8.99 & -5.46 \\
\hline KL 18.1 & massive raft & -9.17 & -1.37 \\
\hline KL 18.2 & thin sparry crust & -9.29 & -2.41 \\
\hline K1 18a & massive raft & -9.32 & -1.66 \\
\hline KL 21 & flowstone & -8.33 & -9.74 \\
\hline $\mathrm{K} 122 \mathrm{a}$ & flowstone & -8.43 & -11.37 \\
\hline $\mathrm{K} 122 \mathrm{~b}$ & $\begin{array}{c}\text { calcite crystal of trilete type, } \\
\text { crystallized just beneath } \\
\text { water table }\end{array}$ & -8.60 & -11.07 \\
\hline $\mathrm{K} 123$ & porous sparry crust & -8.54 & -5.72 \\
\hline
\end{tabular}

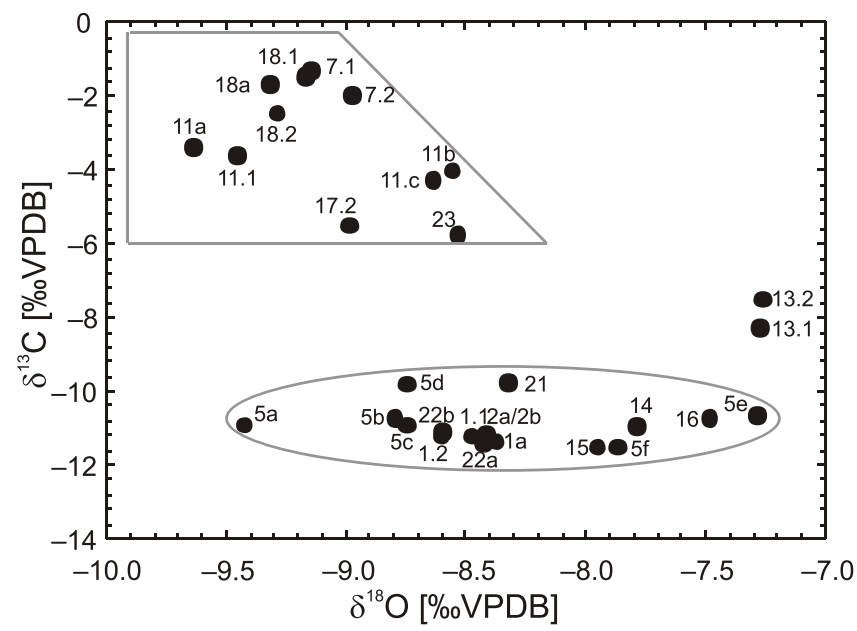

Fig. 15. Carbon and oxygen isotope composition of speleothem samples from the Klęczany Quarry 


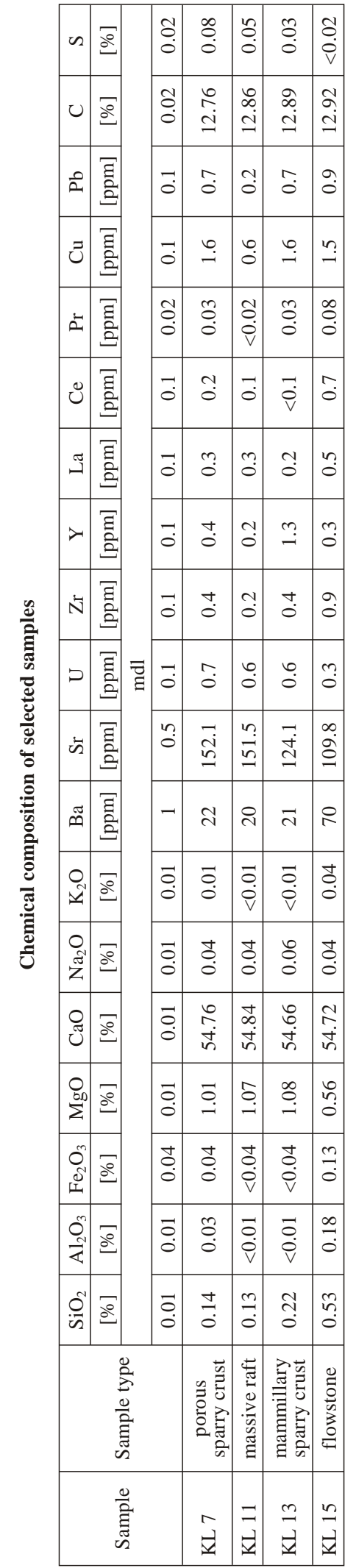

\section{GEOCHEMISTRY}

The chemical composition of four selected samples was analyzed (Table 3). All are composed of low-Mg calcite. The content of $\mathrm{Mg}$ is slightly higher in sparry crusts and rafts than in a flowstone analysed. All samples are characterized by elevated $\mathrm{Na}$ content in comparison with ordinary speleothems. For example, a stalagmite from Chauvet Cave (France) contains between 4.8 and 28.6 ppm Na (Bourdin et al., 2011). Slightly higher values were reported from Lynds Cave stalagmite (Tasmania) varying from 31.5 to 87.8 ppm (Goede and Vogel, 1991). Similarly, all but one samples examined have elevated $S$ content falling between 0.03 and $0.08 \%$. This is also higher than noted so far in speleothems. For example, Wynn et al. (2010) reported a mean content of $\mathrm{S}$ in unpolluted samples of stalagmites the equalled 25 and 14 ppm, respectively from Ernesto Cave (Italy) and Obir Cave (Austria). Unfortunately, comparison of the analytical data from phreatic speleothems is impossible as their chemical compositions have not yet been published.

\section{DISCUSSION}

ORIGIN AND COMPOSITION OF PARENT WATER BASED ON CARBON AND OXYGEN STABLE ISOTOPE COMPOSITION OF SPELEOTHEMS

Theoretically, the $\delta^{13} \mathrm{C}_{\mathrm{TDIC}}$ (TDIC - Total Dissolved Inorganic Carbon) values of carbonate solutions formed with the participation of soil $\mathrm{CO}_{2}$ under open system conditions at about $6^{\circ} \mathrm{C}$ should belong to the range between -11.2 and $-12.2 \%$ for $\mathrm{pCO}_{2}$ equal to 0.001 and $0.01 \mathrm{~atm}$, respectively. Measured $\delta^{13} \mathrm{C}_{\mathrm{TDIC}}$ values forming the lower cluster of points in Figure 15 cover the range from -9.7 to $-11.5 \%$ (with the mean value: $-10.9 \%$ o). Thus, the experimental data are slightly more positive than predicted by the theory. Carbonate solutions before effective precipitation must reach the necessary degree of supersaturation with respect to a given carbonate mineral. This is realized by the $\mathrm{CO}_{2}$ outgassing in which light molecules are preferentially removed from solution to the gaseous phase. During this process the carbonate reservoir remaining in solution becomes progressively enriched in heavy isotopes. After outgassing (just prior to precipitation of carbonates) the $\delta^{13} \mathrm{C}_{\mathrm{TDIC}}$ values may be $2-3 \%$ o higher than at the saturation point (Dulinski and Rozanski, 1990). Due to the short characteristic time of carbon isotope equilibration within the water solution (Hendy, 1971) the $\delta^{13} \mathrm{C}$ values of precipitated carbonate minerals should be close to the carbon isotope composition of the bicarbonate reservoir. It seems that samples representing the lower group of points in Figure 15 formed in this way. It should be noted there that the effective precipitation of carbonates from the solutions formed at $\mathrm{pCO}_{2}$ below 0.003 atm is strongly limited because after outgassing the pressure of $\mathrm{CO}_{2}$ being equivalent to dissolved carbon dioxide is lower than the atmospheric $\mathrm{pCO}_{2}$.

The upper cluster of points in Figure 15 is represented by samples the $\delta^{13} \mathrm{C}$ values of which extend from -5.7 up to $-0.6 \%$, and $\delta^{18} \mathrm{O}$ values are between -9.8 and $-8.5 \%$. All but one, samples belonging to this group formed in phreatic conditions. There are several possible processes leading to enrichment in ${ }^{13} \mathrm{C}$ of the precipitated calcite. The most important of them include: 
1) admixture of geogenic carbon dioxide,

2) influence of atmospheric $\mathrm{CO}_{2}$ in the formation of the carbonate solution,

3) outgassing of $\mathrm{CO}_{2}$ from the solution,

4) isotope exchange between dissolved carbonates and the rock matrix,

5) isotope exchange with atmospheric carbon dioxide.

The carbon isotope composition of geogenic $\mathrm{CO}_{2}$ that occurs widely in the Polish Flysch Carpathians is characterized by $\delta^{13} \mathrm{C}$ $\approx-1 \%$ o (Duliński et al., 2005). Observed $\delta^{13} \mathrm{C}$ values of carbonates precipitated from the solutions controlled by geogenic $\mathrm{CO}_{2}$ are close to $+8 \%$ (Dulinski et al., 1995). Apparently lower values of $\delta^{13} \mathrm{C}$ measured in carbonates from Klęczany and at a significant distance of the quarry from the zone of gaseous $\mathrm{CO}_{2}$ exhalation in the Polish Flysch Carpathians (cf. Chrząstowski and Węcławik, 1992; Leśniak, 1998) indicated rejection of the hypothesis concerning admixture of geogenic $\mathrm{CO}_{2}$.

The carbon isotope composition of pure (not anthropogenically affected) atmospheric carbon dioxide was $-7 \%$ o. Admixture of that $\mathrm{CO}_{2}$ during formation of carbonate solution should increase the $\delta^{13} \mathrm{C}_{\mathrm{TDIC}}$ value. The magnitude of this effect depends on the ratio between atmospheric and soil components. To obtain a $\delta^{13} \mathrm{C}$ of precipitated carbonates equal to about $-6 \%$ o the required partial pressure of soil $\mathrm{CO}_{2}$ should be about $6 \times 10^{-4}$ atm (assuming $\delta^{13} \mathrm{C}$ of the soil $\mathrm{CO}_{2}$ at $-21 \%$ and open system conditions). This pressure is only twice the $\mathrm{pCO}_{2}$ in the bulk atmosphere and, as mentioned earlier, is too low for the effective precipitation of carbonates.

Increase of $\delta^{13} \mathrm{C}_{\text {TDIC }}$ value due to outgassing of $\mathrm{CO}_{2}$ has been already discussed. However, in typical natural conditions the magnitude of this effect is small and cannot explain the enrichment in ${ }^{13} \mathrm{C}$ of carbonate deposits observed.

In groundwaters in contact with rocks containing carbonate minerals isotope exchange between dissolved and solid carbonates occurs (Gonfiantini and Zuppi, 2003). This process is rather slow and requires a long residence time of water in the rock system at a minimum of the order of thousands of years. To change the $\delta^{13} \mathrm{C}_{\text {TDIC }}$ value by $8-10 \%$ o the amount of exchanged carbon should be at least several times higher than in the TDIC reservoir. The influence of this effect on the isotopic composition of some samples cannot be excluded on condition that they were precipitated from groundwaters in distant circulation.

At the final stage of outgassing the pressure of carbon dioxide corresponding to dissolved $\mathrm{CO}_{2}$ is not much different from atmospheric $\mathrm{pCO}_{2}$. Therefore, fluxes of gaseous $\mathrm{CO}_{2}$ "from" and "to" the solution become comparable enabling effective isotope exchange between both carbon reservoirs. The degree and effectiveness of exchange depends on the time of contact of both phases and on the isotopic composition of the gaseous $\mathrm{CO}_{2}$. In closed passages, fissures or caves the gaseous $\mathrm{CO}_{2}$ is often close to chemical and isotopic equilibrium with TDIC. In such conditions, isotope exchange is significantly restricted. In well-ventilated parts of water passages both the concentration and isotope composition of gaseous $\mathrm{CO}_{2}$ are at atmospheric levels. Such conditions are favourable for effective $\mathrm{CO}_{2}$ outgassing and thus, increase of $\delta^{13} \mathrm{C}$ values of precipitated carbonates even above $0 \%$.

The oxygen isotope composition of calcite is controlled by the isotopic composition of water and the temperature of precipitation. In isotopic equilibrium these three variables are linked by the O'Neil formula:

$$
1000 \times \ln \alpha_{\mathrm{C}-\mathrm{W}}=\frac{2.78 \times 10^{6}}{T^{2}}-2.89
$$

where: $\alpha_{\mathrm{C}-\mathrm{w}}=\frac{1000+\delta^{18} \mathrm{O}_{\mathrm{C}}}{1000+\delta^{18} \mathrm{O}_{\mathrm{w}}}$ - equilibrium fractionation coefficient between $\mathrm{C}$ - calcite, $\mathrm{W}$ - water, $T$ - temperature in the absolute scale.

Thus, the palaeoclimatic significance of the oxygen isotope composition of calcite must be always discussed in relation to the composition of the water. Usually, the deuterium content in fluid inclusions provides valuable information about the isotopic composition of oxygen in the water. However, during this study analyses of fluid inclusions were not available. Therefore discussion of the results must be based on general assumptions about the present-day variability and past evolution of the stable isotope composition of groundwaters around Klęczany. This isotopic composition is controlled mainly by temperature and altitude effects. The stable isotope composition of precipitation is usually positively correlated with the mean annual surface temperature prevailing at the precipitation site and has thus oscillated in the past. As a rule the isotopic composition of precipitation changes with the altitude of the terrain and becomes more and more depleted in ${ }^{18} \mathrm{O}$ and ${ }^{2} \mathrm{H}$ at higher elevations. This is called the "altitude effect". In the vicinity of Klęczany the temperature and altitude effects act in parallel to each other. In the Carpathian Mts. the altitude effect can be approximated by the following equation (Zuber et al., 1999):

$$
\delta^{18} \mathrm{O}_{\mathrm{w}}=-0.00172 \times H-9.18
$$

where: $H$ - altitude in $\mathrm{m}$ a.s.l.

Results of $\delta^{18} \mathrm{O}_{\mathrm{C}}$ measurements are shown in Figure 16 for two isotopic compositions of water. A value of $\delta^{18} \mathrm{O}_{\mathrm{H}_{2} \mathrm{O}}=$ $-9.4 \%$ represents the upper limit of the oxygen isotope composition, typical of infiltration waters supplied at present-day climatic conditions at low altitudes in the surrounding area. The second value of $-12.2 \%$ is attributed to groundwaters recharged in colder climatic episodes, probably at the end of the last glaciation and called in brief "glacial waters". For $\delta^{18} \mathrm{O}_{\mathrm{H}_{2} \mathrm{O}}=-9.4 \%$ only four samples (5e, both samples 13 and 16) give reasonable temperatures of formation, comparable with the present-day mean annual value registered at low altitudes. The age of sample 16 supports its formation in climatic conditions similar to those presently occurring in this area. Temperatures indicated by all other samples are above $9.1^{\circ} \mathrm{C}$ and thus, unrealistically high. Occasionally, during glacial declining or short warming episodes within cold periods, independently of positive temperatures, precipitation of carbonates can take place from water recharged in colder conditions and thus, having $\delta^{18} \mathrm{O}_{\mathrm{H}_{2} \mathrm{O}}$ values not correlated with surface temperature. The isotopic composition of precipitated carbonates is lower than those formed from water reflecting the actual surface temperature. In that case, without precise knowledge of the isotopic composition of the water, the temperatures of carbonate deposition are overestimated.

The oxygen isotope composition of water typical of glacial conditions $(-12.2 \%$ ) leads to temperatures in the range from -3.6 to $6.0^{\circ} \mathrm{C}$. As many as 7 samples give negative temperatures. Other samples cover the range from 0 up to $6^{\circ} \mathrm{C}$. 


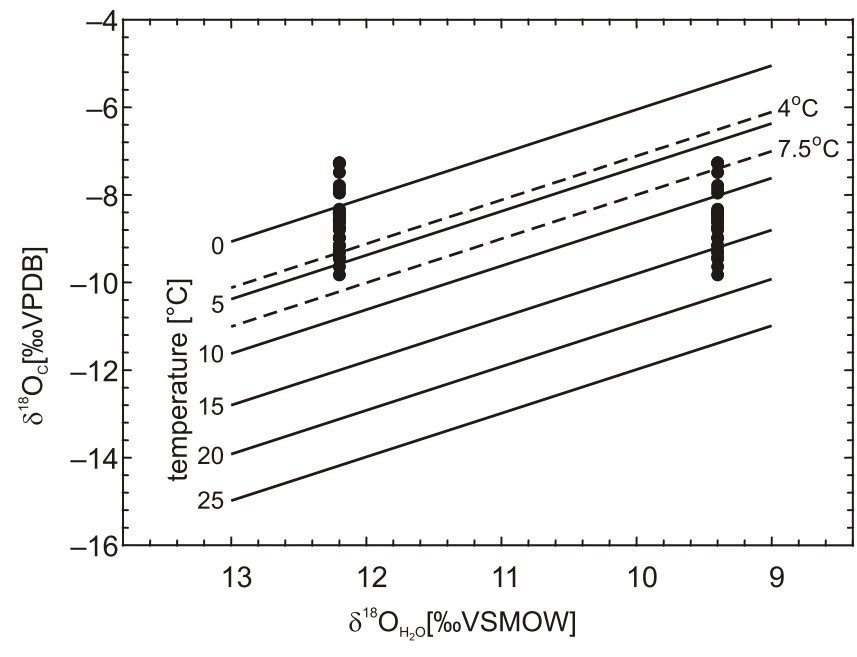

Fig. 16. Relation between oxygen isotope composition of precipitating calcite and water at different temperatures

Dashed lines are referred to the present mean annual temperatures in the middle part of the Nowy Sacz Basin $\left(7.5^{\circ} \mathrm{C}\right)$ and in the peak zone of the mountains $\left(4^{\circ} \mathrm{C}\right)$. Black points represent measured $\delta^{18} \mathrm{O}$ of carbonates. They are plotted for two values of $\delta^{18} \mathrm{O}$ of water: $-9.4 \%$, typical of present infiltration waters recharged at low altitudes, and $-12.2 \%$, being representative for glacial waters

Negative temperatures and those that are too low can reflect the kinetic effect due to escape of gaseous $\mathrm{CO}_{2}$ from solution. As a result the $\delta^{18} \mathrm{O}_{\mathrm{C}}$ becomes more positive leading to the underestimation of precipitation temperatures.

Groundwaters presently recharged at moderate altitudes in the Nowy Sącz Basin are characterized by $\delta^{18} \mathrm{O}_{\mathrm{H}_{2} \mathrm{O}}$ values averaging $-10.6 \%$ o. Such an isotopic composition of water and the measured $\delta^{18} \mathrm{O}_{\mathrm{C}}$ values determine the range of possible temperatures at between 2 and $12.5^{\circ} \mathrm{C}$. For about $30 \%$ of samples the calculated temperatures are also unrealistically high.

The $\delta^{18} \mathrm{O}_{\mathrm{H}_{2} \mathrm{O}}=-11.1 \%$ is the minimum value at which the measured isotope composition of all carbonate samples covers the range of positive temperatures, between 0 and $10.5^{\circ} \mathrm{C}$. For only six samples, the temperature exceeds $8^{\circ} \mathrm{C}$. However this isotopic composition of water corresponds to a mean elevation of recharge area at about $1200 \mathrm{~m}$ a.s. 1 which is comparable with the highest mountain peaks located $25-30 \mathrm{~km} \mathrm{SW}$ of the quarry. As the recharge area cannot be limited to peaks only it is obvious that the inferred $\delta^{18} \mathrm{O}_{\mathrm{H}_{2} \mathrm{O}}$ must be higher. As a consequence more carbonate samples would reveal formation temperatures that are too high.

\section{NON-CARBONATE ADMIXTURES IN PARENT WATER}

All speleothems analysed were precipitated from relatively clean water which did not contain substantial siliciclastic admixtures. This is shown by a lack of impurities visible under the microscope and by geochemical data, such as negligible amounts of $\mathrm{Si}, \mathrm{Al}$ and $\mathrm{Fe}$ in all samples studied (Table 3). The ${ }^{230} \mathrm{Th} /{ }^{232} \mathrm{Th}$ activity ratio is also a significant indicator of detrital admixture (Table 1). It is routinely used as an indicator of the reliability of U-Th ages. Usually samples with a ratio >20 are regarded as devoid of significant amounts of thorium-bear- ing fine-grained detrital components. In the samples studied the ${ }^{230} \mathrm{Th} /{ }^{232} \mathrm{Th}$ activity ratio ranges from 24 to above 100 . Excluding two samples (KL 7) the isotopic composition of which has been modified by postcrystallization processes, the lowest ratio of ${ }^{230} \mathrm{Th} /{ }^{232} \mathrm{Th}$ characterizes the flowstones (Table 1 ). Conversely, water table and phreatic speleothems yield the highest values of the ${ }^{230} \mathrm{Th} /{ }^{232} \mathrm{Th}$ ratio. This is in line with the lower amounts of such elements as $\mathrm{Si}, \mathrm{Al}, \mathrm{Fe}$, and $\mathrm{Zr}$ in these types of speleothems (Table 3).

\section{ORIGIN OF ATYPICAL CALCITE CRYSTALS}

Phreatic calcites and thin rafts are composed of atypical calcite crystals, which implies very specific conditions for their growth. Similar crystals have been described from environments where water is highly saturated with respect to calcium carbonate, as for example hot-springs (Folk et al., 1985; Chafetz et al., 1991; Jones et al., 2005). There, carbonates are formed under a high degree of disequilibrium. This is a general term proposed to embrace several interrelated factors controlling disequilibrium crystallization (Jones and Renaut, 1995).

Such factors as rapid degassing of $\mathrm{CO}_{2}$ leading to increases of saturation indices and in consequence to rapid formation of carbonate minerals must be ruled out when discussing the Klęczany case due to several reasons. All these factors operate in hot-spring systems containing water highly charged with deep-seated $\mathrm{CO}_{2}$. There, vigorous outgassing of $\mathrm{CO}_{2}$ leads to a strong kinetic fractionation of isotopes (Chafetz et al., 1991; Chafetz and Lawrence, 1994; Guo et al., 1996). As a consequence, crystallizing calcites have $\delta^{13} \mathrm{C}$ substantially higher than those discussed from Klęczany. Moreover, in a stagnant water body degassing is definitely more effective in the zone located just near the air-water interface. Thus, crystals with morphologies significantly affected by degassing should be formed exclusively or predominantly in this zone. Conversely, the crystals discussed form thin rafts as well as phreatic spar, that is speleothems developed at different depths below the water table. Thus, one can expect different conditions corresponding to different growth rates of crystals.

The presence of ions other than $\mathrm{Ca}$ and $\mathrm{HCO}_{3}$ may be another factor influencing the disequilibrium during crystallization (Jones and Renaut, 1995). For instance, Folk et al. (1985) put forward a hypothesis explaining the curvature of faces in gothic-arch calcite by incorporation of $\mathrm{SO}_{4}$ groups into calcite crystals. These relatively large ions caused the deformation of calcite faces. Quaternary calcite cements in the Sellafield area (Cumbria, UK) may serve as another example (Milodowski et al., 1998). These cements, growing below the "saline transition zone", where chloride concentration in water is abruptly shifted, display elongated forms, in contrast to cements formed over above zone. A similar phenomenon was observed in the case of calcite from the Tono area in Honsiu, Japan (Iwatsuki et al., 2002). Moreover, the controls of foreign ions on calcite morphology have been experimentally confirmed (Paquette and Reeder, 1995; Ruiz-Agudo et al., 2011). The elevated content of $\mathrm{Na}$ and $\mathrm{S}$ in the calcites studied from Klęczany in comparison to other speleothems seems to provide an important indication (Table 3). 


\section{CLIMATIC AND TOPOGRAPHIC CONDITIONS} OF SPELEOTHEM GROWTH

It is now generally accepted that speleothems grow efficiently during warm and humid climatic conditions. The ages of speleothems obtained from Klęczany seem to generally support the above rule. This is shown by their comparison with speleothem growth frequency curve constructed for the Carpathians (Fig. 14; Hercman, 2000).

The growth periods of some speleothems from Klęczany are also well-correlated with marine isotope stages (MIS, see Imbrie et al., 1984; Martinson et al., 1987). They fall into MIS 1 (Holocene), MIS 5a and MIS 7 (Fig. 14). However, some exceptions are observed. Three samples labelled as KL 1, KL 11 and KL 13, representing thin raft, massive raft and mammillary sparry crust, respectively, crystallized between $35 \mathrm{ka}$ and $26.2 \mathrm{ka}$, that is in the relatively warmer MIS 3 and colder MIS 2, but not during the last glacial maximum (MIS 2). Similarly, samples KL 11 and KL 11-1 (massive rafts) seem to have formed during the cold MIS 6. However, several speleothems of this age are known from central and western Europe (see Hercman et al., 1997, 2008; Plagnes, 2002). Thus, the age of the speleothems studied suggests that their growth was in some way climatically controlled, as for the majority of speleothems from solution caves.

The presence of speleothems of known age sheds some light on palaeohydrological and palaeotopographic conditions (Ford, 1973; Ford et al., 1993; Hercman et al., 2008). Calcite rafts may provide valuable information in this field. They were formed strictly at the level of the water table. The oldest rafts yield an age $230_{-13}^{+14} \mathrm{ka}$. The location of the water table was mainly governed by the entrenchment of the neighbouring valley. This shows that the water table at that time was located ap- proximately at an altitude 390-400 m. Thus, one can expect that the valley bottom around $230 \mathrm{ka}$ was located approximately at the same position as it is at present. On the other hand, the finding of series of the rafts cemented to the fissure walls indicates fluctuations of the water table after their formation. However, these fluctuations were not significant since the substantially younger rafts occur approximately at the same elevation (see Table 1 and Fig. 8A).

The intact massive rafts which are cemented and link opposite sides of the fissures show that at least some fissures have not been widened since the time of raft formation. The fissure must have been open before raft formation.

\section{PROPOSED SCENARIO OF SPELEOTHEM GROWTH}

This brief discussion of the most important effects potentially influencing both the $\delta^{13} \mathrm{C}$ and $\delta^{18} \mathrm{O}$ of speleothems from the Klęczany Quarry as well as their morphology and the presence of atypical crystals indicate the ambiguity of processes leading to their formation. The diversity of isotopic composition observed makes explanation of their genesis difficult. Therefore, any model formulated must be more or less speculative. The postulated scenario of precipitation of the calcite speleothems is given below (Fig. 17). Both its merits and disadvantages are thoroughly discussed.

The proposed scenario assumes the participation of two different waters in precipitation of the carbonates. An analogous situation was described from caves in the Black Hills, where some speleothems precipitated from infiltration or ascending water (Bakalowicz et al., 1987; Ford, 1989; Ford et al., 1993). The Klęczany Quarry is situated within a tectonic window in which the seeps of oil were formerly observed (Matl, 1975). Szpakiewicz

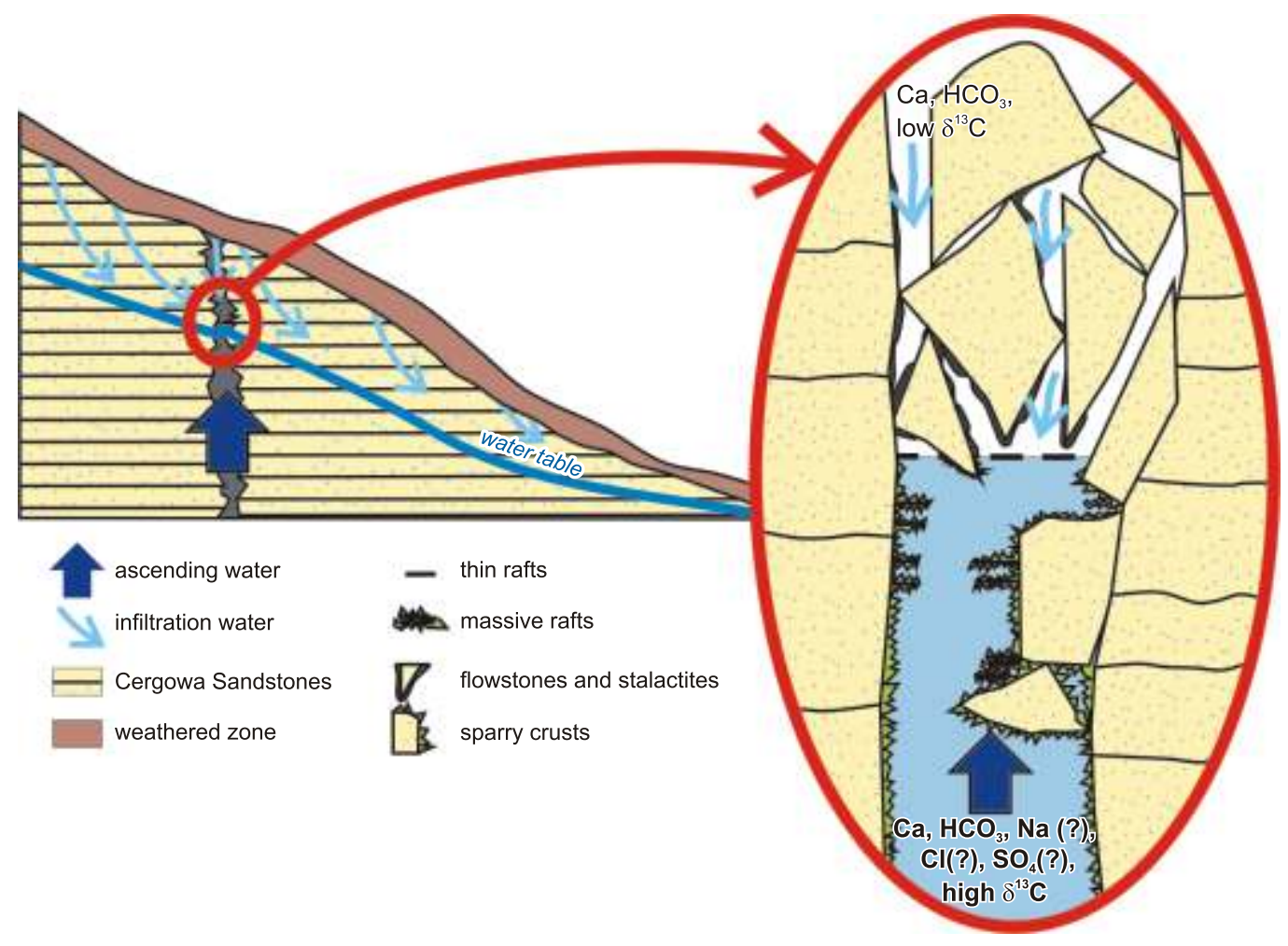

Fig. 17. Model depicting the growth conditions of speleothems in Klęczany 
(1976) has described the presence of highly mineralized water (>25 g/L) at a depth of about $500 \mathrm{~m}$ below the surface. Water of this type is known from the Polish Outer Carpathians (e.g., Oszczypko and Zuber, 2002). It ascends to the surface along fault zones (Chowaniec, 2009, fig. 37). Moreover, the formation of recent tufa in the Mszana Dolna tectonic window, which can serve as an analogue to the Klecczany tectonic window, is ascribed to spring zones of deeply-circulating water (Gruszczyński and Mastella, 1986). Thus, in the past, the occurrence of ascending water of deep circulation was probable in the Klęczany area. Such water must have been recharged at elevations exceeding the altitude at the Klęczany Quarry. It must have been characterized by lower $\delta^{18} \mathrm{O}_{\mathrm{H}_{2} \mathrm{O}}$ values than infiltration waters in the vicinity of the quarry. Also its transition time could be sufficiently long for significant carbon isotope exchange between the dissolved carbonates and the rock matrix. This water could contain dissolved $\mathrm{CaCO}_{3}$ not only from the Cergowa Sandstones but, as seems plausible, also from underlying rocks. Carbonates precipitating from such water should be more negative in $\delta^{18} \mathrm{O}$ and simultaneously more positive in $\delta^{13} \mathrm{C}$ than those deposited from the solutions formed by local meteoric water with the participation of soil $\mathrm{CO}_{2}$. The phreatic speleothems: calcite sparry crusts and massive rafts found in the quarry could precipitate from this water. They form the upper cluster of points in Figure 15.

The meteoric water infiltrating through the soil layer is the second water influx the importance of which in precipitation of the speleothems is assumed in this scenario. It flowed down the fissure walls in the vadose zone and filled the fissures in the upper phreatic zone. This water dissolved the Cergowa Sandstones. Due to $\mathrm{CO}_{2}$ outgassing, the $\delta^{13} \mathrm{C}$ of the dissolved carbonate reservoir was shifted up $2 \%$ o towards higher values whereas the $\delta^{18} \mathrm{O}$ was shifted insignificantly or remained unaltered (as a result of oxygen isotope exchange between bicarbonates and water). On the fissure walls where the thin film of this water seeped down, the flowstones and stalactites precipitated. The thin rafts formed in stagnant water. Samples precipitated from this type of water are represented in Figure 15 by the lower cluster of points.

This scenario explains satisfactorily the stable isotope composition of the carbonates. It also clarifies the lack of detrital impurities in the phreatic and water table speleothems.

However, the scenario also has a few disadvantages. It cannot fully explain the similarity of calcite crystals belonging to samples forming the upper cluster of points in Figure 15, that is sparry crusts and massive rafts with thin rafts falling into the lower cluster. Theoretically, mixing of ascending and meteoric waters may be considered. According to the above discussion the calcite rafts would be an analogue for speleothems formed in mixing-zone caves, which abound in rafts and subaqueous speleothems (Csoma et al., 2006; Fornós et al., 2009; van Hengstum et al., 2011). But on the other hand, assuming the necessity of mixing of both types of water, it is difficult to explain the lack of speleothems which yield moderate values of stable isotope composition.

The lack of detrital impurities in flowstones cannot be explained either. Formed from infiltrating water passing through the soil zone and dissolving calcareous sandstones, they should contain substantial amounts of detrital admixtures. However, the flowstone samples are of high purity. This phenomenon may re- flect the purification of seepage water between the weathered zone and the open fissure where the flowstones crystallized.

The proposed scenario explains abundance of unique phreatic and, to some extent, also water table speleothems in the Klęczany Quarry since they are associated with the zone of water ascent. Thus, a scarcity of analogous calcites in the Outer Carpathians is expected. Conversely, speleothems precipitated from infiltrating water should be widely distributed also in other regions of the Carpathians, especially in areas where carbonate-bearing rocks have contact with infiltration water. Indeed, some speleothems have been found in non-karst caves developed in the Cergowa Sandstones (Urban et al., 2007b). However, those speleothems contain substantial amounts of non-carbonate detrital admixtures, and so differ from the speleothems discussed from Klęczany. Such detrital material is especially prone to be introduced into subsurface open fissures (Gradziński et al., 2010).

\section{CONCLUSIONS}

1. Peculiar calcite speleothems in the Klęczany Quarry represent vadose, water table and phreatic forms, that is flowstones and stalactites, thin and massive rafts and various types of sparry crust.

2. The speleothems are composed of calcite crystals, some of which are of eccentric morphology. Such crystals are common in thin rafts and in sparry crusts. The origin of these crystals may be linked with the presence of foreign ions in the parent water.

3 . The speleothems yield ages between $230_{-13}^{+14} \mathrm{ka}$ and Holocene. They crystallized during warm periods - MIS 7, MIS 5a and MIS 1, during the warm MIS 3 cold MIS 2 boundary interval as well as during the cold MIS 6. This suggests that their growth was to some extent climatically controlled.

4. Phreatic speleothems, including massive rafts, precipitated from ascending water of deep circulation. They are characterized by $\delta^{18} \mathrm{O}$ values ranging from -9.8 to $-8.5 \%$ and $\delta^{13} \mathrm{C}$ values ranging from -5.7 to $-0.6 \%$ o. Crystallizing vadose and water table speleothems were fed with local infiltration water charged with soil $\mathrm{CO}_{2}$. They are more negative in $\delta^{13} \mathrm{C}$ and more positive in $\delta^{18} \mathrm{O}$ than phreatic speleothems. Near the water table the waters mixed, which affected the morphology of crystal composing the thin rafts.

5. The water table in the Klęczany area before quarrying was at a similar level as at more than $230 \mathrm{ka}$. Thus, the bottom of the valley is also in a similar position.

Acknowledgements. The Klęczany Stone Resources Company Ltd kindly gave permission for the fieldworks. The authors wish to thank several colleagues with whom they discussed the complex topic of calcites from the Klęczany Quarry, that is M. Cieszkowski, B. Jones, E. Koszowska, J. Kowal, S. Leszczyński, A. Lewandowska, L. Rajchel and J. Urban. Z. Banach and B. Zych are acknowledged for operating the SEM, S. Borczak for providing data on sandstone porosity, W. Obcowski for taking photographs, and R. Jach for her patience during the preparation of the figures. D. Ford and an anonymous reviewer, as well as GQ editor T. Peryt helped to improve the manuscript. 


\section{REFERENCES}

BAKALOWICZ M.I., FORD D.C., MILLER T.E., PALMER A.N. and PALMER M.V. (1987) - Thermal genesis of dissolution caves in the Black Hills, South Dakota. GSA Bull., 99: 729-738.

BINKLEY K., WILKINSON B.H. and OWEN R.M. (1980) - Vadose beachrock cementation along southeastern Michigan marl lake. J. Sedim. Petrol., 50: 953-962.

BOURDIN C., DOUVILLE E. and GENTY D. (2011) - Alkaline-earth metal and rare-earth metal incorporation control by ionic radius and growth rate of stalagmite from the Chauvet Cave, Southeastern France. Chem. Geol., 290: 1-11.

BOURDON B., HENDERSON G., LUNDSTROM C. and TURNER S. (2003) - Uranium-series geochemistry. Rev. Miner. Geochem., 52 $1-565$.

BRUTHANS J., SCHWEIGSTILLOVA J., JENČ P., CHURÁČKOVA L. and BEZDIČKA P. (2012) $-{ }^{14} \mathrm{C}$ and U-series dating of speleothems in the Bohemian paradise (Czech republic): retreat rates of sandstone cave walls and implications for cave origin. Acta Geodinam. Geomater., 9: 93-108.

CHAFETZ H.S. and GUIDRY S.A. (2003) - Deposition and diagenesis of Mammoth Hot Springs travertine: Yellowstone National Park, Wyoming, USA. Can. J. Earth Sc., 40: 1515-1529.

CHAFETZ H.S. and LAWRENCE J. R. (1994) - Stable isotopic variability within modern travertines. Géogr. Phys. Quatern., 48: 257-273.

CHAFETZ H.S., RUSH P.F. and UTECH N.M. (1991) - Microenvironmental controls on mineralogy and habit of $\mathrm{CaCO}_{3}$ precipitates: an example from an active travertine system. Sedimentology, 38: 107-126.

CHOWANIEC J. (2009) - Hydrogeology study of the western part of the Polish Carpathians (in Polish with English summary). Biul. Państw. Inst. Geol., 434: 1-98.

CHRZĄSTOWSKI J. and WĘCŁAWIK S. (1992) - Balneological resources of the Magura Nappe (Polish Carpathians) (in Polish with English summary). Prz. Geol., 40 (7): 417-429.

CIESZKOWSKI M. (1992) - Michalczowa zone: a new unit of the fore-Magura zone, Outer West Carpathians, South Poland (in Polish with English summary). Geologia, Kwart. AGH, 18: 1-125.

CIESZKOWSKI M. and ŚLACZKA A. (2001) - The Polish Carpathians general geology. In: Przewodnik LXXII Zjazdu Polskiego Towarzystwa Geologicznego, 12-15 września 2001: 99-108. Państw. Inst. Geol., Kraków.

CSOMA A.É., GOLDSTEIN R.H. and POMAR L. (2006) - Pleistocene speleothems of Mallorca: implications for palaeoclimate and carbonate diagenesis in mixing zone. Sedimentology, 53: 213-236.

DICKSON J.A.D. (1993) - Crystal growth diagrams as an aid to interpreting the fabrics of calcite aggregates. J. Sedim. Petrol., 63: 1-17.

DUBLYANSKY Y.V. (2000) - Dissolution of carbonates by geothermal waters. In: Speleogenesis. Evolution of Karst Aquifers (eds. A.B. Klimchouk, D.C. Ford, A.N. Palmer and W. Dreybrodt): 158-159. National Speleological Society, Huntsville.

DULINSKI M. and ROZANSKI K. (1990) - Formation of ${ }^{13} \mathrm{C} /{ }^{12} \mathrm{C}$ isotope ratios in speleothems: a semi-dynamic model. Radiocarbon, 32: 7-16.

DULIŃSKI M., GRABCZAK J., KOSTECKA A. and WĘCŁAWIK S. (1995) - Stable isotope composition of spelean calcites and gaseous $\mathrm{CO}_{2}$ from Tylicz (Polish Carpathians). Chem. Geol., 125: 271-280.

DULIŃSKI M., RAJCHEL L. and RAJCHEL J. (2005) - Chemical and isotope investigations of the exhalation in Tylicz. Współczesne Problemy Hydrogeologii, 12: 189-196.

DUNHAM R. (1969) - Early vadose silt in Townsend Mound (reef), New Mexico. SEPM Spec. Publ., 14: 139-182.

FLOREK W. (2009) - Dodatek nr 5 do dokumentacji geologicznej zło a piaskowców "magurskich" litologicznie cergowskich "Klęczany". Unpubl. Report. Arch. Klęczany Stone Resources Company Ltd.

FOLK R.L., CHAFETZ H.S. and TIEZZI P.A., (1985) - Bizarre forms of depositional and diagenetic calcite in hot-spring travertines, central Italy. SEPM Spec. Publ., 36: 349-369.

FORD D.C. (1973) - Development of the Canyons of the South Nahanni River, N.W.T. Can. J. Earth Sc., 10: 366-378.
FORD D.C. (1989) - Features of the genesis of Jewel Cave and Wind Cave, Black Hills, South Dakota. Nat. Speleol. Soc. Bull., 51: 100-110.

FORD D.C., LUNDBERG J., PALMER A.N., PALMER M.V., DREYBRODT W. and SCHWARCZ H.P. (1993) - Uranium-series dating of the draining of an aquifer: the example of Wind Cave, Black Hills, South Dakota. GSA Bull., 105: 241-250.

FORNÓS J.J., GINÉS J. and GRÀCIAF. (2009) - Present-day sedimentary facies in the coastal karst caves of Mallorca Island (western Mediterranean). J. Cave Karst Studia, 71: 86-99.

FOUKE B.W., FARMER J., des MARAIS D.J., PRATT L., STURCGIO N.C., BURNS P.C. and DISCIPULO M. (2000) - Depositional facies and aqueous-solid geochemistry of travertine-depositing hot springs (Angel Terrace. Mammoth Hot Springs. Yellowstone National park, U.S.A.). J. Sedim. Res., 70: 565-585.

FRISIA S., BORSATO A., FAIRCHILD J.I. and MCDERMOTT F. (2000) - Calcite fabrics, growth mechanisms, and environments of formation in speleothems from the Italian Alps and southwestern Ireland. J. Sedim. Res., 70: 1183-1196.

GARY M.O. and SHARP J.M. Jr. (2006) - Volcanogenic karstification of Sistema Zacatón, Mexico. GSA Spec. Pap., 404: 79-89.

GOEDE A. and VOGEL J.C. (1991) - Trace element variations and dating of a Late Pleistocene Tasmanian speleothem. Palaeogeogr. Palaeoclimatol. Palaeoecol., 88: 121-131.

GONFIANTINI R. and ZUPPI G.M. (2003) - Carbon isotope exchange rate of DIC in karst groundwater. Chem. Geol., 197: 319-336.

GONZÁLEZ L.A., CARPENTER S.J. and LOHMANN K.C. (1992) - Inorganic calcite morphology: roles of fluid chemistry and fluid flow. J. Sedim. Petrol., 62: 382-399.

GORKA P. and HERCMAN H. (2002) - URANOTHOR v. 2.6. Delphi Code of calculation program and user guide. MS, Archive of Quaternary Geology Department, Institute of Geological Sciences, PAS, Warsaw.

GORNITZ V. and SCHREIBER Ch. (1981) - Displacive halite hoppers from the Dead Sea: some implications for ancient evaporite deposits. J. Sedim. Petrol., 51: 787-794.

GRADZIŃSKI M., ROSPONDEK M. and SZULC J. (1997) Paleoenvironmental controls and microfacies variability of the flowstone cover from Zvoniva Cave in the Slovakian Karst. Slov. Geol. Mag., 3: 299-313.

GRADZIŃSKI M., CHMIEL M.J., LEWANDOWSKA A. and MICHALSKA-KASPERKIEWICZ B. (2010) - Siliciclastic microstromatolites in a sandstone cave: Role of trapping and binding of detrital particles in formation of cave deposits. Ann. Soc. Geol. Pol., 80: $303-314$.

GRUSZCZYŃSKI M. and MASTELLA L. (1986) - Calcareous tufas in the area of the Mszana Dolna tectonic window (in Polish with English summary). Ann. Soc. Geol. Pol., 56: 117-131.

GUO L. and RIDING R. (1998) - Hot-spring travertine facies and sequences, Late Pleistocene, Rapolano Terme, Italy. Sedimentology, 45: $163-180$.

GUO L., ANDREWS J., RIDING R., DENNIS P. and DRESSER Q. (1996) - Possible microbial effects on stable carbon isotopes in hot-spring travertines. J. Sedim. Res., 66: 468-473.

HENDY C.H. (1971) - The isotopic geochemistry of speleothems - I. The calculation of the effects of different modes of formation on the isotopic composition of speleothems and their applicability as palaeoclimatic indicators. Geochim. Cosmochim. Acta, 35: 801-824.

HERCMAN H. (2000) - Reconstruction of palaeoclimatic changes in central Europe between 10 and 200 thousand years BP, based on analysis of growth frequency of speleothems. Studia Quatern., 17: 35-70.

HERCMAN H., BELLA P., GŁAZEK J., GRADZIŃSKI M., LAURITZEN S.-E. and LØVLIE R. (1997) - Uranium-series of speleothems from Demänova Ice Cave: a step to age estimation of the Demänova Cave System. Ann. Soc. Geol. Pol., 67: 439-450.

HERCMAN H., GRADZIŃSKI M. and BELLA P. (2008) - Evolution of Brestovská Cave based on U-series dating of speleothems. Geochronometria, 32: 112. 
HILL C. and FORTI P. (1997) - Cave Minerals of the World. National Speleological Society, Huntsville.

IMBRIE J., HAYS J.D., MARTINSON D.G., McINTYRE A., MIX A.C., MORLEY J.J., PISIAS N.G., PRELL W.L. and SHACKLETON N.J. (1984) - The orbital theory of Pleistocene climate: support from a revised chronology of the marine ${ }^{18} \mathrm{O}$ record. In: Milankovitch and $\mathrm{Cli}-$ mate, Understanding the Response to Astronomical Forcing. Part I. (eds. A. Berger, J. Imbrie, J. Hays, G. Kukla and B. Saltzman): 269-305. Reidel, Dordrecht.

IVANOVICH M. and HARMON R.S. (1992) - Uranium Series Disequilibrium. Applications to Environmental Problems. Clarendon, Oxford.

IWATSUKI T., SATAKE H., METCALFE R., YOSIHIDA H. and HAMA K. (2002) - Isotopic and morphological features of fracture calcite from granitic rocks of the Tonto area, Japan: a promising palaeohydrological tool. App. Geochem., 17: 1241-1257.

JANSSEN A., SWENNEN R., PODOOR N. and KEPPEN E. (1999) - Biological and diagenetic influence in Recent and fossil tufa deposits from Belgium. Sedim. Geol., 126: 75-95.

JONES B. (1989) - Calcite raft, peloids, and micrite in cave deposits from Cayman Brac, British West Indies. Can. J. Earth Sc., 26: 654-664.

JONES B. and PENG X. (2012) - Intrinsic versus extrinsic controls on the development of calcite dendrite bushes, Shuzhishi Spring, Rehai geothermal area, Tengchong, Yunnan Province, China. Sedim. Geol., 249-250: 45-62.

JONES B. and RENAUT R.W. (1995) - Noncrystallographic calcite dendrites from hot-spring deposits at Lake Bogoria, Kenya. J. Sedim. Res., A65: 154-169.

JONES B., RENAUT R.W., OWEN R.B. and TORFASON H. (2005) Growth patterns and implications of complex dendrites in calcite travertines from Lýsuhóll, Snæfellsen, Iceland. Sedimentology, 52: $1277-1301$.

KENDALL A.C and BROUGHTON P.L. (1978) - Origin of fabrics in speleothems composed of columnar calcite crystals. J. Sedim. Petrol., 48: $519-538$

KOSTECKA A. (1992) - Calcite veins in travertines at Bešeňova (Liptovska Kotlina basin, Slovakia). Miner. Pol., 23: 3-12.

KOSTECKA A. (1993) - Calcite from the Quaternary spring waters at Tylicz, Krynica, Polish Carpathians. Sedimentology, 40: 27-39.

KOSTECKA A. and WECEAWIK S. (1987) - Mineral water deposits in vicinity of Tylicz (Beskid Niski Range, Polish Flysch Carpathians). Ann. Soc. Geol. Pol., 57: 37-58.

KOWAL J. (2009) - Geology of the Klecczany-Limanowa tectonic window in surroundings of Marcinkowice (in Polish with English summary). Unpubl. MSc. Thesis, Institute of Geological Sciences, Jagiellonian Univeristy, Kraków.

LESZCZYŃSKI S. and MALATA E. (2002) - Sedimentary conditions in the Siary Zone of the Magura Basin (Carpathians) in the late Eocene-early Oligocene. Ann. Soc. Geol. Pol., 72: 201-239.

LESZCZYŃSKI S. and MALIK K. (1996) - Carbonates in flysch of the Polish Outer Carpathians (in Polish with English summary). Prz. Geol., 44 (2): 151-158.

LEŚNIAK P.M. (1998) - Origin of carbon dioxide and evolution of $\mathrm{CO}_{2}$-rich waters in the West Carpathians, Poland. Acta Geol. Pol., 48 : 343-366.

MARTINSON D.G., PISIAS N.G., HAYS J.D., IMBRIE J., MOORE T.C. and SHACKLETON N.J. (1987) - Age dating and the orbital theory of the Ice Ages: development of a High-Resolution 0 to 300,000 year chronostratigraphy. Quatern. Res., 27: 1-29.

MATL K. (1975) - Surowce energetyczne. In: Surowce mineralne regionu krakowskiego (ed. M. Kamieński). Wyd. Geol., Warszawa.

MILODOWSKI A.E., GILLESPIE M.R., NADEN J., FORTEY N.J., SHEPHERD T.J., MEARCE J.M. and METCALFE R. (1998) - The petrology and paragenesis of fracture mineralization in the Sellafield area, west Cumbria. Proc. York. Geol. Soc., 52: 215-241.

MÜLLER P. (1989) - Hydrothermal paleokarst of Hungary. In: Paleokarst, a Systematic and Regional Review (eds. P. Bosák, D.C. Ford, J. Głazek and I. Horáček): 155-163. Akademia, Prague.
OSZCZYPKO N. (2008) - Outer Carpathians in Poland. In: The Geology of Central Europe, 2: Mesozoic and Cenozoic (ed. T. McCann): 1078-1081. The Geological Society, London.

OSZCZYPKO N. and ZUBER A. (2002) - Geological and isotopic evidence of diagenetic waters in the Polish Flysch Carpathians. Geol. Carpath., 53: 257-268.

OSZCZYPKO N., CHOWANIEC J. and KONCEWICZ A. (1981) Waterpressure test of the Magura sandstones (in Polish with English summary). Ann. Soc. Geol. Pol., 51: 273-302.

PAQUETTE J. and REEDER R.J. (1995) - Relationship between surface structure, growth mechanisms, and trace element incorporation in calcite. Geochim. Cosmochim. Acta, 59: 735-749.

PLAGNES V., CAUSSE C., GENTY D., PATERNE M. and BLAMART D. (2002) - A discontinuous climatic record from 187 to $74 \mathrm{ka}$ from a speleothem of the Clamouse Cave (south of France). Earth Planet. Sc. Lett., 201: 87-103.

RAINEY D.K. and JONES B. (2009) - Abiotic versus biotic controls on the development of the Fairmont Hot Springs carbonate deposit, British Columbia, Canada. Sedimentology, 56: 1832-1857.

RENAUT R.W., JONES B. and Le TURDU C. (1999) - Calcite lilypads and ledges at Lorusio Hot springs, Kenya Rift valley: travertine precipitation at the air-water interface. Can. J. Earth Sc., 36: 649-666.

RUIZ-AGUDO E., PUTNIS Ch.V., WANG L. and PUTINS A. (2011) Specific effects of background electrolytes on the kinetics of step propagation during calcite growth. Geochim. Cosmochim. Acta, 75: 3803-3814

SELF C.A. and HILL C.A. (2003) - How speleothems grow: an introduction to the ontogeny of cave minerals. J. Cave Karst. Studia, 65; $130-153$.

SOUTHGATE P.N. (1982) - Cambrian skeletal halite crystals and experimental analogues. Sedimentology, 29: 391-407.

STADNIK R. (2009) - Sedimentary development of the Cergowa Beds of the Grybów Unit (Klęczany quarry), Polish Western Carpathians (in Polish with English summary). Geologia, Kwart. AGH, 35: 23-29.

SZPAKIEWICZ M. (1976) - Mineral waters of the central part of Polish Carpathians in the light of new cartographic data (in Polish with English summary). Biul. Geol., 21: 323-334.

TAYLOR P.M. and CHAFETZ H.S. (2004) - Floating rafts of calcite crystals in cave pools, central Texas, U.S.A.: Crystal habit vs. saturation state. J. Sedim. Res., 74: 328-341.

TAYLOR M.P., DRYSDALE R.N. and CARTHEW K.D. (2004) - The formation and environmental significance of calcite rafts in tropical tufa-depositing rivers of northern Australia. Sedimentology, 51: 1089-1101.

TURGEON S. and LUNDBERG J. (2001) - Chronology and discontinuities and petrology of speleothems as paleoclimatic indicators of the Klamath Mountains, southwestern Oregon. Carbon. Evapor., 16: 153-167.

URBAN J., MARGIELEWSKI W., SCHEJBAL-CHWASTEK M. and SZURA Cz. (2007a) - Speleothems in some caves of the Beskidy Mts., Poland. Nature Conserv., 63: 109-117.

URBAN J., MARGIELEWSKI W., ŽÁK K., HERCMAN H., SUJKA G. and MLECZEK T. (2007b) - The calcareous speleothems in the pseudokarst Jaskinia Słowiańska-Drwali cave, Beskid Niski Mts., Poland. Nature Conserv., 63: 119-128.

Van HENGSTUM P.J., SCOTT D.B., GRÖCKE D.R. and CHARETTE M.A. (2011) - Sea level controls sedimentation and environments in coastal caves and sinkholes. Mar. Geol., 286: 35-50.

WELLS A.C. (1971) - Cave calcite. Studia Speleol., 2: 129-148.

WYNN P.M., FAIRCHILD I.J., FRISIA S., SPÖTL Ch., BAKER A. and BORSATO A. (2010) - High-resolution sulphur isotope analysis of speleothem carbonate by secondary ionisation mass spectrometry. Chem. Geol., 271: 101-107.

ZUBER A., CIE KOWSKI W., GRABCZAK J. and DULIŃSKI M. (1999) - Tritium ages and altitude of recharge areas of mineral waters in Krynica, estimated from tritium, $\delta^{18} \mathrm{O}$ and $\delta \mathrm{D}$ ddata (in Polish with English summary). Prz. Geol., 47 (6): 574-583. 